\title{
KETERKAITAN KELIMPAHAN UNSUR MAJOR DAN MINOR DENGAN ZONASI LATERIT NIKEL BLOK HZ (HARZBURGIT) DAN DN (DUNIT) DAERAH PULAU PAKAL, HALMAHERA TIMUR
}

\author{
RELATION OF MAJOR AND MINOR ELEMENTS ENRICHMENT \\ WITH NICKEL LATERITE ZONATION IN HARZBURGITE (HZ) \\ AND DUNITE (DN) BLOCKS AT PAKAL ISLAND, EAST HALMAHERA
}

\author{
Fiandri I. Rinawan', Mega F. Rosana1, Mohammad N. Heriawan², \\ dan Euis T. Yuningsih ${ }^{1}$ \\ ${ }^{1}$ Fakultas Teknik Geologi, Universitas Padjadjaran \\ ${ }^{2}$ Fakultas Teknik Pertambangan dan Perminyakan, ITB \\ irfiandri@gmail.com
}

\section{ABSTRAK}

Keterkaitan kelimpahan unsur pada profil laterit nikel dilakukan berdasarkan hasil analisis kimia unsur major $\left(\mathrm{Fe}, \mathrm{SiO}_{2}, \mathrm{MgO}\right.$, dan $\left.\mathrm{Al}_{2} \mathrm{O}_{3}\right)$ dan minor $\left(\mathrm{Ni}, \mathrm{Co}, \mathrm{MnO}\right.$, dan $\left.\mathrm{Cr}_{2} \mathrm{O}_{3}\right)$ menggunakan analisis univariat dan multivariat. Profil berupa tanah atau hancuran batuan hasil lapukan litologi ultrabasa harzburgit (Blok HZ) dan dunit (Blok DN) berumur Kapur hingga Jura, terletak di daerah Pulau Pakal, Halmahera Timur. Tujuan penelitian ini yaitu untuk mengetahui hubungan antar unsur kimia major dan minor terhadap nilai koefisien korelasi kuat hingga sangat kuat baik negatif maupun positif yang terdistribusi pada profil laterit nikel Blok $\mathrm{HZ}$ dan DN. Penelitian ini fokus pada identifikasi fisik mineralogi bedrock dan analisis kimia profil laterit nikel. Identifikasi fisik di Blok HZ melibatkan 436 conto berasal dari 19 pemboran, kedalaman $10 \mathrm{~m}$ hingga $40 \mathrm{~m}$. Adapun identifikasi fisik di Blok DN melibatkan 650 conto berasal dari 16 pemboran, kedalaman $11 \mathrm{~m}$ hingga $57 \mathrm{~m}$. Komposisi mineral di Blok HZ terdiri dari mineral oksida besi limonit, gutit, jarosit, dan oksida mangan (zona limonit); krisopras, garnierit, magnetit, hematit, serpentin-krisotil, dan stiktit (zona saprolit); olivin-forsterit, piroksen-ortopiroksen, dan kromit (zona boulderlbedrock). Sedangkan di Blok DN terdiri dari mineral oksida besi limonit, gutit, dan oksida mangan (zona limonit); krisopras, jarosit, garnierit, magnetit, hematit, mineral lempung montmorilonit, kuarsa, serpentin-krisotil, dan talk (zona saprolit), olivin-forsterit, piroksen-hastingsit, dan kromit (zona boulderlbedrock). Analisis statistik univariat menunjukkan distribusi data relatif tidak normal dengan koefisien variasi > 0,5 . Pada analisis statistik multivariat mengindikasikan nilai koefisien korelasi positif maupun negatif pada zonasi laterit nikel berupa hubungan unsur yang sangat kuat $( \pm 0,80-1,00)$ dengan jumlah korelasi dominan. Koefisien korelasi pada Blok $\mathrm{HZ}$ diantaranya mengindikasikan pasangan unsur yang berkorelasi sangat kuat yaitu: unsur major-major ( $\mathrm{Fe}$ vs $\mathrm{MgO}, \mathrm{Fe}$ vs $\mathrm{SiO}_{2}, \mathrm{SiO}_{2}$ vs $\mathrm{MgO}$, dan $\mathrm{MgO}$ vs $\mathrm{Al}_{2} \mathrm{O}_{3}$ ), minor-minor (Co vs $\mathrm{MnO}$ ) serta majorminor $\left(\mathrm{Al}_{2} \mathrm{O}_{3}\right.$ vs $\mathrm{Cr}_{2} \mathrm{O}_{3}$, Fe vs $\mathrm{Co}$, Fe vs $\mathrm{MnO}$, dan $\mathrm{SiO}_{2}$ vs $\mathrm{Co}$ ). Sedangkan pada Blok DN pasangan unsur yang berkorelasi sangat kuat yaitu: unsur major-major ( $\mathrm{Fe}$ vs $\mathrm{MgO}$ ), minorminor (Co vs $\mathrm{MnO}$ ) dan major-minor ( $\mathrm{Fe}$ vs $\mathrm{Co}, \mathrm{Fe}$ vs $\mathrm{Cr}_{2} \mathrm{O}_{3}, \mathrm{Fe}$ vs $\mathrm{MnO}, \mathrm{MgO}$ vs $\mathrm{Co}$, dan $\mathrm{MgO}$ vs $\mathrm{MnO}$ ). Hal ini berkaitan dengan posisi masing-masing korelasi distribusi unsur kimia major dan minor tersebut pada zona profil laterit nikel Limonit, Saprolit dan Boulder/Bedrock.

Kata kunci: Analisis korelasi, unsur major-minor, profil laterit nikel, ultrabasa, harzburgit, dunit

\section{ABSTRACT}

Relation of element enrichment in nickel laterite profiles was processed based on major elements ( $\mathrm{Fe}, \mathrm{SiO}_{2}, \mathrm{MgO}, \mathrm{Al}_{2} \mathrm{O}_{3}$ ) and minor elements ( $\mathrm{Ni}, \mathrm{Co}, \mathrm{MnO}, \mathrm{Cr}_{2} \mathrm{O}_{3}$ ) chemical analysis using univariate and multivariate analyisis. Profiles such as soil or rock powder from weathered results of ultrabasic lithology of harzburgite (HZ Block) and dunite (DN Block), Cretaceous- 
Jurasic ages located in Pakal Island, East Halmahera. The main purpose of this research is to analyze the major and minor elements association related to the strong to very strong correlation which distributed in nickel laterite profile in the block of $H Z$ and $D N$. This research focused on the physical identification and chemical analysis of nickel laterite profile. In $\mathrm{HZ}$ block involved of 436 samples from 19 drillholes, $10 \mathrm{~m}$ to $40 \mathrm{~m}$ depths and in DN block involved 650 samples from 16 drillholes, $11 \mathrm{~m}$ to $57 \mathrm{~m}$ depths. Mineral composition result showed that in $\mathrm{HZ}$ block were: limonite iron oxide, goethite, jarosite, mangan oxide (limonite zone); chrysoprase, garnierite, magnetite, hematite, montmorilonite clay mineral, serpentinechrysotile, stictite (saprolite zone); and olivine-forsterite, orthopyroxene, chromite (boulder/bedrock zone); and mineralogical composition in DN block were: limonite iron oxide, goethite, mangan-oxide, jarosite, (limonite zone); chrysoprase, garnierite, magnetite, hematite, clay-mineral, quartz, serpentine talc (saprolite zone); olivine-forsterite, pyroxene-hastingsite, and chromite (bedrock/boulder zone). Univariate statistical analysis showed that the data distribution were not normal with Coefficient of Variation (CoefVar) >0.5. In multivariate statistical analysis indicated the positive and negative correlation coefficients in nickel laterite zoning in the form of very strong elements relationships $( \pm 0.80-1.00)$ with the number of dominant correlations. The correlation coefficients in $\mathrm{HZ}$ block indicated the strong correlation of elements pair i.e. major-major ( $\mathrm{Fe}$ vs $\mathrm{MgO}, \mathrm{Fe}$ vs $\mathrm{SiO}_{2}, \mathrm{SiO}_{2}$ vs $\mathrm{MgO}, \mathrm{MgO}$ vs $\mathrm{Al}_{2} \mathrm{O}_{3}$ ), minorminor (Co vs MnO) dan major-minor elements $\left(\mathrm{Al}_{2} \mathrm{O}_{3}\right.$ vs $\mathrm{Cr}_{2} \mathrm{O}_{3}$, Fe vs Co, Fe vs $\mathrm{MnO}, \mathrm{SiO}_{2}$ vs Co). While in DN Block indicated the strong correlation of elements pair i.e. major-major (Fe vs $\mathrm{MgO}$ ), minor-minor (Co vs $\mathrm{MnO}$ ) dan major-minor elements ( $\mathrm{Fe}$ vs $\mathrm{Co}, \mathrm{Fe}$ vs $\mathrm{Cr}_{2} \mathrm{O}_{3}, \mathrm{Fe}$ vs $\mathrm{MnO}, \mathrm{MgO}$ vs Co, $\mathrm{MgO}$ vs MnO). Those major-minor elements association correlation distribution were shown in each base position zone of nickel laterite such as limonite, saprolite and boulder/bedrock.

Keywords: correlation analysis, major-minor elements, nickel laterite profile, ultramafic, harzburgite, dunite

\section{PENDAHULUAN}

PT ANTAM Tbk., mempunyai prospek IUP eksplorasi komoditas laterit nikel yang berlokasi di daerah Pulau Pakal, Kecamatan Maba, Kabupaten Halmahera Timur, Provinsi Maluku Utara. Daerah tersebut menempati kompleks batuan ultrabasa, dunit, piroksenit dan serpentinit berumur Kapur hingga Jura, sebagai batuan dasar endapan sekunder laterit nikel. Batuan dasar ini merupakan bagian dari seri ofiolit kerak samudra (Ishiwatari, 1994). Seri ofiolit di daerah Halmahera sebagai segmen yang terangkat oleh proses geotektonik obduksi dan struktur sesar naik, yang kemudian lapuk dan tererosi hingga tersingkap batuan ultrabasa dunit dan peridotit (Harris, 2003).

Pada daerah Pakal tersebut di atas, telah dilakukan eksplorasi oleh Unit Geomin (2013) berupa pemetaan geologi, geofisika, dan pemboran dan analisis kimia laterit nikel. Selain itu di Pulau Pakal telah dilakukan penyelidikan oleh peneliti terdahulu, diantaranya terkait hubungan geomorfologi dan profil laterit nikel oleh Syafrizal (2009) dan tentang kriteria terkait perhitungan sumber daya laterit nikel oleh Augusman (2009).

Variabilitas dan heterogenitas kondisi laterit nikel berkaitan dengan karakteristik keberadaan komposisi fisik, komposisi kimia, sifat fisik, sifat kimia, dan komposisi profil laterit nikel. Zonasi profil laterit nikel ini terdiri dari boulder/bedrock, saprolit, limonit, dan top soil. Masing-masing zonasi dicirikan oleh komposisi distribusi unsur kimia $\mathrm{Ni}$, terutama pada zona saprolit yang mempunyai komposisi $\mathrm{Ni}$ yang tinggi $(\geq 2 \%)$.

Berkaitan dengan hal tersebut, maka dirancang studi geologi laterit nikel, dengan melakukan pemetaan geologi, pengambilan conto pemboran pada profil 
laterit nikel dari permukaan hingga batuan dasar dunit atau peridotit (harzburgit).

Analisis kimia dilakukan pada zonasi top soil, limonit, saprolit hingga boulderlbedrock. Masing-masing zonasi ini mempunyai komposisi kimia unsur major, dengan klasifikasi $>3 \%$ yaitu $\mathrm{Fe}, \mathrm{SiO}_{2}$, $\mathrm{MgO}, \mathrm{Al}_{2} \mathrm{O}_{3}$ dan unsur minor dengan klasifikasi $<3 \%$, yaitu $\mathrm{Ni}$, Co, $\mathrm{MnO}, \mathrm{Cr}_{2} \mathrm{O}_{3}$ (Ahmad, 2006).

Studi ini difokuskan pada identifikasi profil laterit nikel, berkaitan dengan data hasil deskripsi komposisi fisik conto pemboran laterit dan data hasil analisis kimia unsur major dan minor yang disajikan melalui analisis statistik univariat berupa statistik deskriptif, histogram dan plot probabilitas dan multivariat berupa analisis korelasi. Sedangkan tujuannya yaitu untuk mengetahui hubungan antar unsur major dan minor yang menempati dan terakumulasi pada conto profil laterit nikel Top Soil, Limonit, Saprolit dan Boulder/Bedrock.

Hal tersebut bertujuan untuk mengidentifikasi ciri karakteristik distribusi unsur kimia pada profil laterit nikel secara spesifik terhadap batuan dasar tersebut maupun hasil pelapukannya. Maka dalam penelitian ini, metode analisis multivariat digunakan untuk mengkaji hubungan antar unsur major dan minor. Metode ini secara kuantitatif dapat memfasilitasi pemahaman tentang interpretasi zonasi laterit nikel. Metode ini berguna untuk menentukan unsur-unsur yang saling berkorelasi kuat hingga sangat kuat antara unsur major dan minor sebagai unsur-unsur yang dapat menginterpretasikan kondisi zonasi laterit nikel. Adapun hasil analisis multivariat tersebut dikaitkan dengan hasil deskripsi conto pemboran untuk mendapatkan gambaran kesesuaian antara hasil analisis multivariat dengan deskripsi conto pemboran.

\section{GEOLOGI REGIONAL DAN GEOLOGI DAERAH PENELITIAN}

Daerah Halmahera Timur diapit oleh pola sesar naik berarah Utara-Selatan dan Barat Laut-Tenggara yang mengakibatkan seri ofiolit bagian bawah dapat tersingkap. Geologi regional Halmahera Timur meliputi lengan Timurlaut, dan Lengan Tenggara. Morfologi mandala ini terdiri dari pegunungan berlereng terjal yang merupakan pencerminan dari batuan ultrabasa dan morfologi karst batugamping, sedangkan morfologi dengan perbukitan yang relatif rendah dan lereng yang landai mencerminkan batuan sedimen (Apandi dan Sudana, 1980). Batuan ultrabasa menempati pulau-pulau kecil di sebelah Timur Pulau Halmahera, salah satunya Pulau Pakal (Gambar 1). Stratigrafi regional daerah penelitian disusun oleh kompleks batuan ultrabasa (Ub) merupakan batuan tertua, diperkirakan berumur Kapur hingga Jura. Jenis litologi pada formasi ini terdiri dari serpentinit, piroksenit, dan dunit yang umumnya berwarna hitam, getas, kebanyakan terpecah, terbreksikan, setempat mengandung asbes dan garnierit.

Berdasarkan hasil penelitian Rinawan (2012), Pulau Pakal tersusun oleh batuan ultramafik Dunit dan Harzburgit terserpentinisasi. Satuan stratigrafi daerah penelitian terdiri dari satuan batuan dunit (Ycd), satuan batuan harzburgit (Ych), dan aluvium (Qa) (Gambar 2). Satuan batuan dunit (Ycd) menempati daerah Pulau Pakal berkisar seluas $30 \%$ di sekitar Selatan, Tenggara dan Timur Laut daerah penelitian. Satuan batuan harzburgit (Ych) menempati daerah Pulau Pakal berkisar seluas $60 \%$ di sekitar baratdaya-baratlaututara-timurlaut-tenggara daerah penelitian. Kedua satuan batuan tersebut berumur Kapur-Jura yang disebandingkan dengan stratigrafi regional kompleks batuan ultrabasa (Apandi dan Sudana, 1980). 
Aluvium (Qa) menempati daerah pantai Pulau Pakal berkisar seluas $10 \%$ daerah penelitian. Aluvium ini disebandingkan dengan stratigrafi regional aluvium dan endapan pantai berumur Kuarter (Apandi dan Sudana, 1980).

Struktur geologi Pulau Pakal terjadi terutama pada litologi satuan batuan dunit dan harzburgit yang dicirikan dengan indikasi struktur yang kuat dijumpai pada singkapan batuan tersebut berupa kekar dan retakan (Rinawan, 2012). Berdasarkan data yang diperoleh dari singkapan kekar dan retakan menunjukkan bahwa struktur diinterpretasikan sebagai sesar naik dengan arah umum tegasan adalah NESW.

Indikasi struktur baik pada batuan dunit maupun harzburgit berkaitan adanya kekar dan retakan yang diindikasikan sebagai kriteria persyaratan terbentuknya laterit nikel di daerah tropis (Ahmad, 2006). Melalui bidang-bidang sesar, kekar, dan retakan akan menyebabkan kemudahan perkolasi air sehingga terjadinya pelapukan batuan.

Satuan batuan dunit terangkat oleh struktur sesar naik memotong satuan batuan harzburgit dengan arah jurus struktur NNESSW terdapat pada bagian barat daya Pulau Pakal. Tersingkapnya satuan batuan dunit di permukaan dikarenakan batuan diatasnya tererosi.

Satuan batuan harzburgit terangkat oleh struktur sesar naik memotong satuan batuan harzburgit dengan arah jurus struktur NNW-SSE terdapat memanjang di bagian tengah Pulau Pakal.

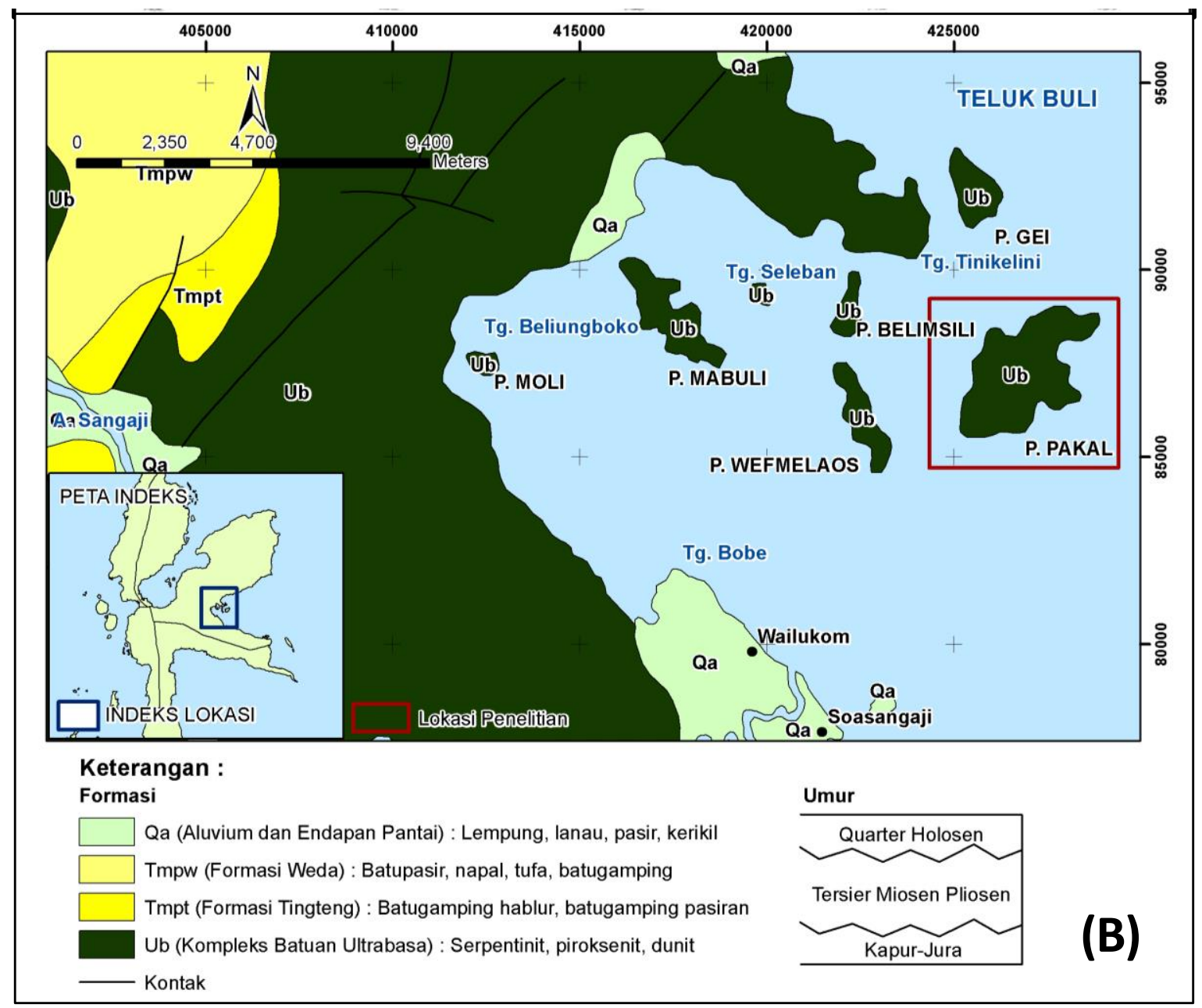

Gambar 1. Geologi Regional Daerah Tanjung Buli dan sekitarnya

(Apandi dan Sudana, 1980, modifikasi 


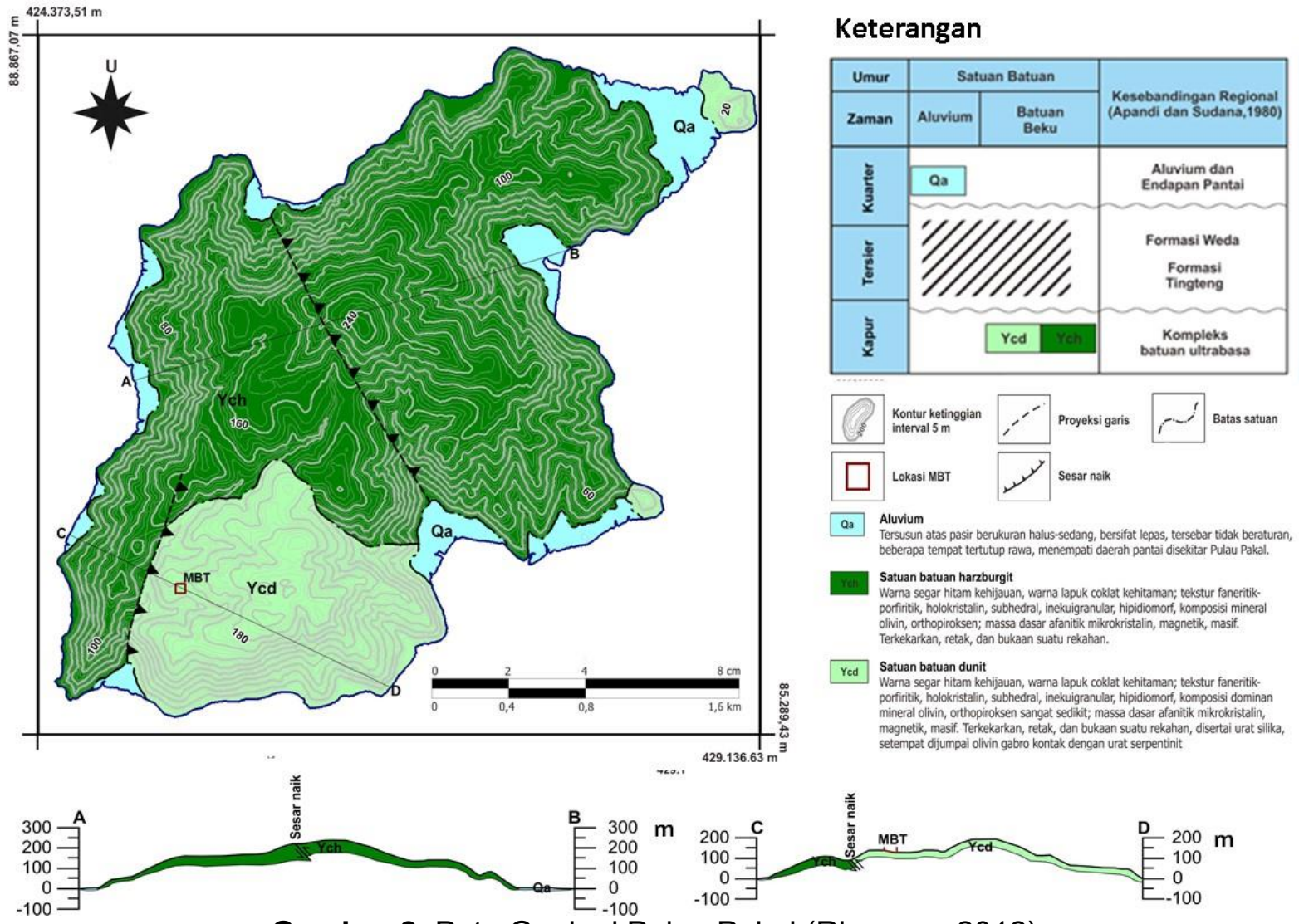

Gambar 2. Peta Geologi Pulau Pakal (Rinawan, 2012)

\section{METODOLOGI}

Conto tanah dan batuan per meter diambil dari pemboran profil laterit nikel pada 2 daerah yaitu (Gambar 3): Blok HZ luas \pm 12 hektar, sebanyak 436 conto dari 19 bor, dengan kedalaman $10 \mathrm{~m}$ s.d. $41 \mathrm{~m}$, dan Blok DN, luas \pm 9 hektar, sebanyak 650 conto dari 16 bor, dengan kedalaman $11 \mathrm{~m}$ s.d. $57 \mathrm{~m}$. Daerah blok HZ dan Blok DN, masing-masing menempati satuan batuan harzburgit dan satuan batuan dunit (Rinawan, 2012).

Identifikasi fisik conto terpilih dari inti pemboran dilakukan secara megaskopis, petrografi, mineragrafi, dan XRD.

Adapun 4 unsur major yaitu $\mathrm{Fe}, \mathrm{SiO}_{2}, \mathrm{MgO}$, $\mathrm{Al}_{2} \mathrm{O}_{3}$ dan 4 unsur minor yaitu $\mathrm{Ni}, \mathrm{Co}, \mathrm{MnO}$, $\mathrm{Cr}_{2} \mathrm{O}_{3}$ dianalisis dengan metode XRF. Hasil analisis kimia 8 unsur kimia tersebut, digunakan sebagai database kimia dalam melakukan statistik multivariat yaitu analisis korelasi unsur major dan minor.
Pengolahan data diawali dengan penggunaan metode statistik deskriptif untuk unsur major dan minor terhadap variabel: mean, median, stDev, koefisien variasi, nilai minimum, nilai maksimum, skewness, dan kurtosis. Selanjutnya digambarkan histogram setiap unsur kimia major dan minor, masing-masing untuk blok $\mathrm{HZ}$ dan $\mathrm{DN}$ secara keseluruhan maupun per zona laterit.

Selanjutnya digunakan metode statistik multivariat berupa analisis korelasi untuk menentukan hubungan antara dua variabel yang saling berkaitan satu sama lainnya. Adapun koefisien korelasi ( $r$ ) digunakan sebagai satuan besaran: besar-kecilnya nilai hubungan antara dua variabel yang dinyatakan dalam satuan jumlah korelasi dengan kisaran nilai $-1<r<+1$. Setiap nilai korelasi mempunyai tingkatan nilai hubungan (Sugiyono, 1999). 


\section{MAKALAH ILMIAH}

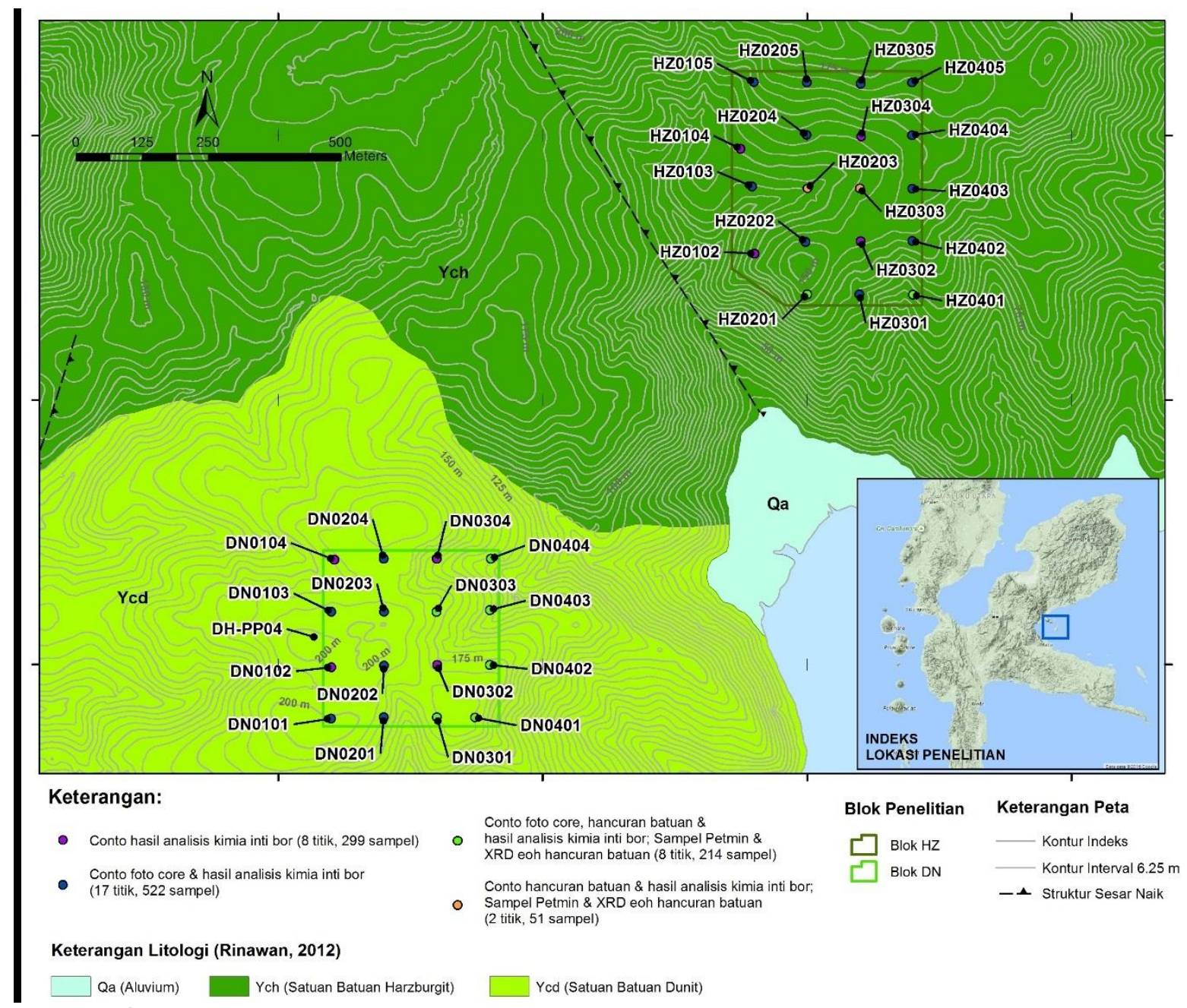

Gambar 3. Peta lokasi pengambilan conto laterit nikel Daerah Pulau Pakal

\section{HASIL}

\section{Identifikasi Fisik}

Identifikasi fisik berdasarkan metode megaskopik, serta ditunjang metode analisis petrografi, mineragrafi dan XRD dari conto batuan dasar terpilih Harzburgit (Blok HZ) dan Dunit (Blok DN). Berdasarkan hasil pemboran, pada Blok $\mathrm{HZ}$ terdapat 19 titik bor pada zona profil laterit nikel yang menunjukkan gradasi warna top soil, limonit, saprolit, boulder/bedrock (Gambar 5A):

- zona top soil terdapat pada kisaran kedalaman 0 s.d. 2 meter; berwarna kemerahan kecoklatan, mengandung bahan organik dan lempung.

- zona limonit terdapat pada kisaran kedalaman 1 s.d. 19 meter; berwarna kemerahan kecoklatan, ditandai soil bermineral lempung, silika, oksida besi gutit-limonit-oksida mangan, jarosit, hematit-magnetit dan kromit).

- zona saprolit terdapat pada kisaran kedalaman 11 s.d. 37 meter; berwarna kekuningan-kecoklatan ditandai lapukan batuan menjadi soil, berciri relik tekstur batuan asal, bermineral lempung, gutit, hematit, serpentin, krisopras, garnierit, olivin, piroksen.

- zona boulderlbedrock terdapat pada kisaran kedalaman 3 s.d. 6,4 s.d. 6,6 s.d. 9,11 s.d. $11.65,13$ s.d. $13.5,14$ s.d. $16,15.2$ s.d. $16,16,3$ s.d. 19,17 s.d. 18.5 , 18 s.d. 22 , 19.7 s.d. $20,20.4$ s.d. $21,20.3$ s.d. 22,21 s.d. 24,22 s.d. 26 , 23 s.d. 25 meter; berkomposisi mineral oksida besi limonit, gutit, garnierit, jarosit, oksida mangan, krisopras, magnetit, hematit, serpentin-krisotil, stiktit, olivin-forsterit, piroksenortopiroksen dan kromit (Gambar 4A.). 
Pada Blok DN dunit, terdapat 16 titik bor pada zona profil laterit nikel menunjukkan gradasi warna top soil, limonit, saprolit, boulder/bedrock (Gambar 5B):

- zona top soil terdapat pada kisaran kedalaman 0 s.d. 5 meter; berwarna kemerahan kecoklatan, mengandung bahan organik dan lempung.

- zona limonit terdapat pada kisaran kedalaman 3 s.d. 51 meter, berwarna kecoklatan, ditandai soil bermineral lempung montmorilonit, silika, oksida besi gutit-limonit-oksida mangan, jarosit, hematit-magnetit dan kromit.

- zona saprolit terdapat pada kisaran kedalaman 31 s.d. 57 meter; berwarna kekuningan-kecoklatan ditandai lapukan batuan menjadi soil, berciri relik tekstur

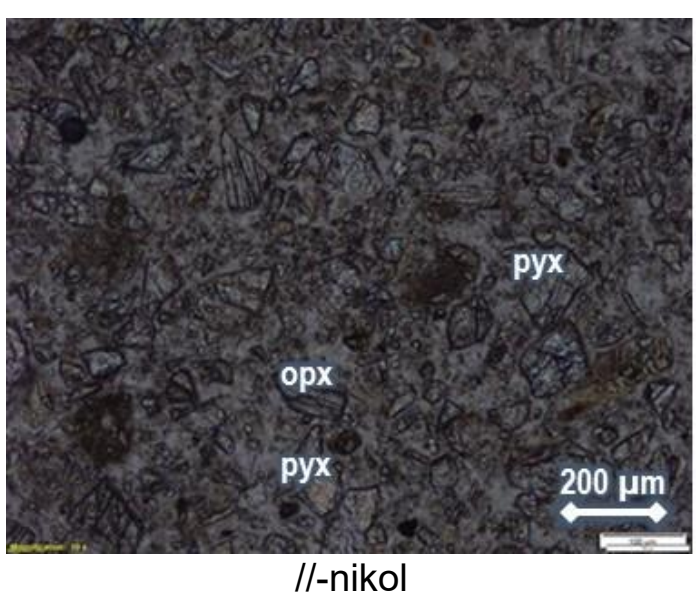

(B)

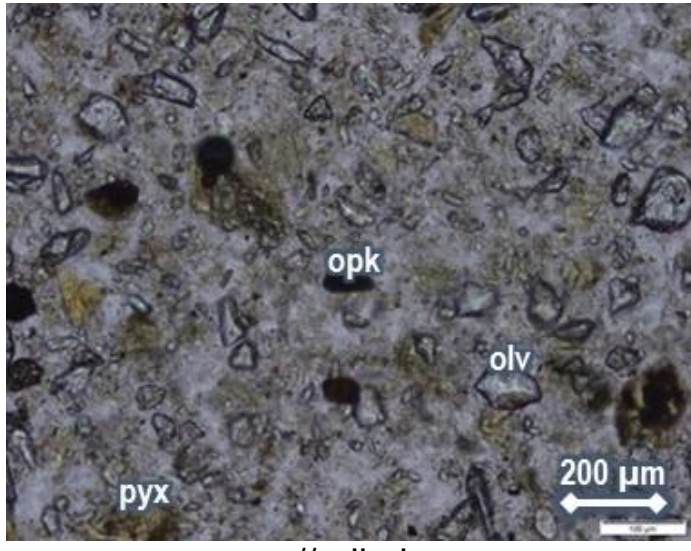

I/-nikol

(A) batuan asal, bermineral lempung, gutit, oksida mangan, hematit, serpentinkrisotil, krisopras, garnierit, olivin, dan piroksen.

- zona boulderlbedrock terdapat pada kisaran kedalaman 2.3 s.d. 3, 3.7 s.d. 5, 5 s.d. $5.3,5.6$ s.d

11, 12 s.d. $13,13.4$ s.d. $16.65,17$ s.d. $17.45,17$ s.d. $21,18.3$ s.d. $19,21.6$ s.d. 25.6, 22 s.d. $27.6,32.5$ s.d. $33,35.35$ s.d. 38,37 s.d. 40,39 s.d. $40.6,34.7$ s.d. $35,41.4$ s.d. 43,43 s.d. 49,47 s.d. 47.4 , 49.6 s.d. 50,51 s.d. 51.8 meter, warna kelabu kekuningan-kelabu berkomposisi mineral silika, magnetit, hematit, serpentin-krisotil, stiktit, talk, olivinforsterit, piroksen-ortopiroksen, hastingsit, dan kromit (Gambar 4B.).
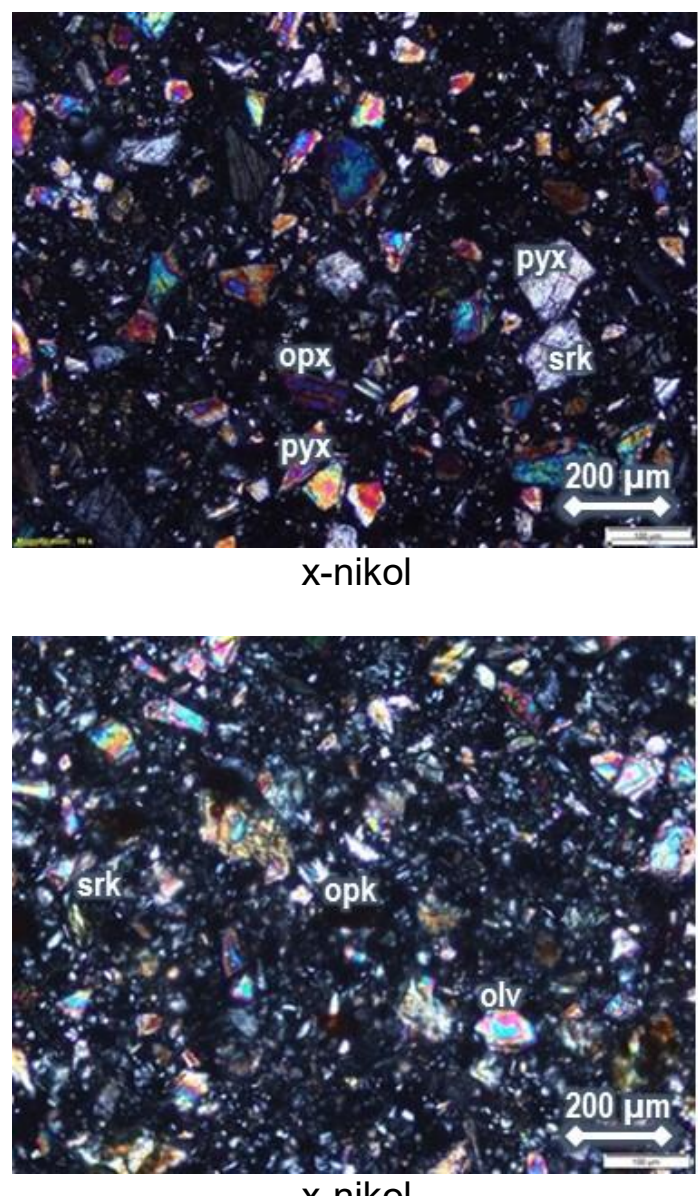

$\mathrm{x}$-nikol

Keterangan : Olv: Olivin; Pyx: piroksen; Opx: orthopiroksen; Srk: serpentin krisotil; Opk: Opak kromit

Gambar 4. Foto mikroskopik sayatan tipis conto: A, lokasi HZ0204; B, lokasi DN0303 


\section{MAKALAH ILMIAH}

(A)

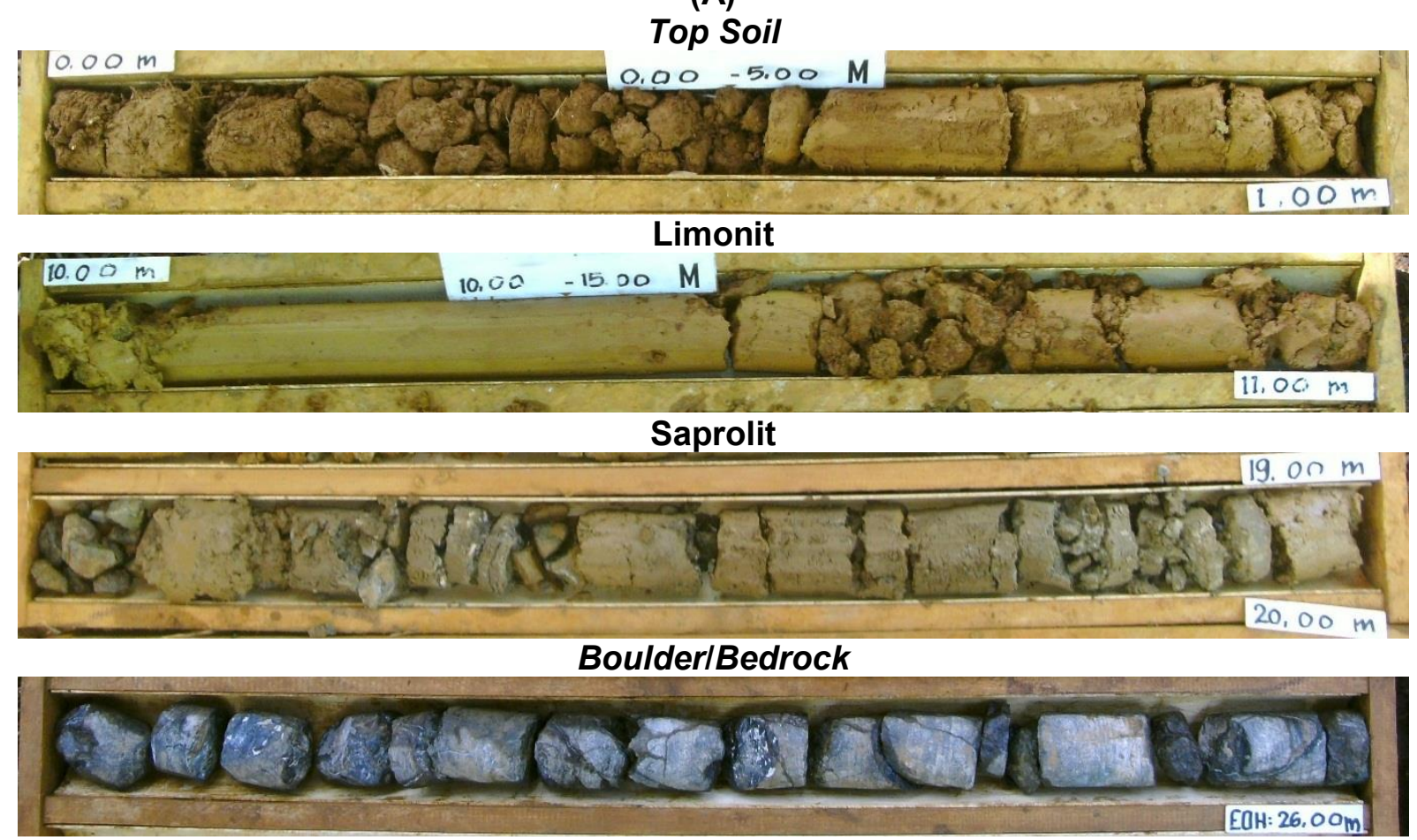

(B)
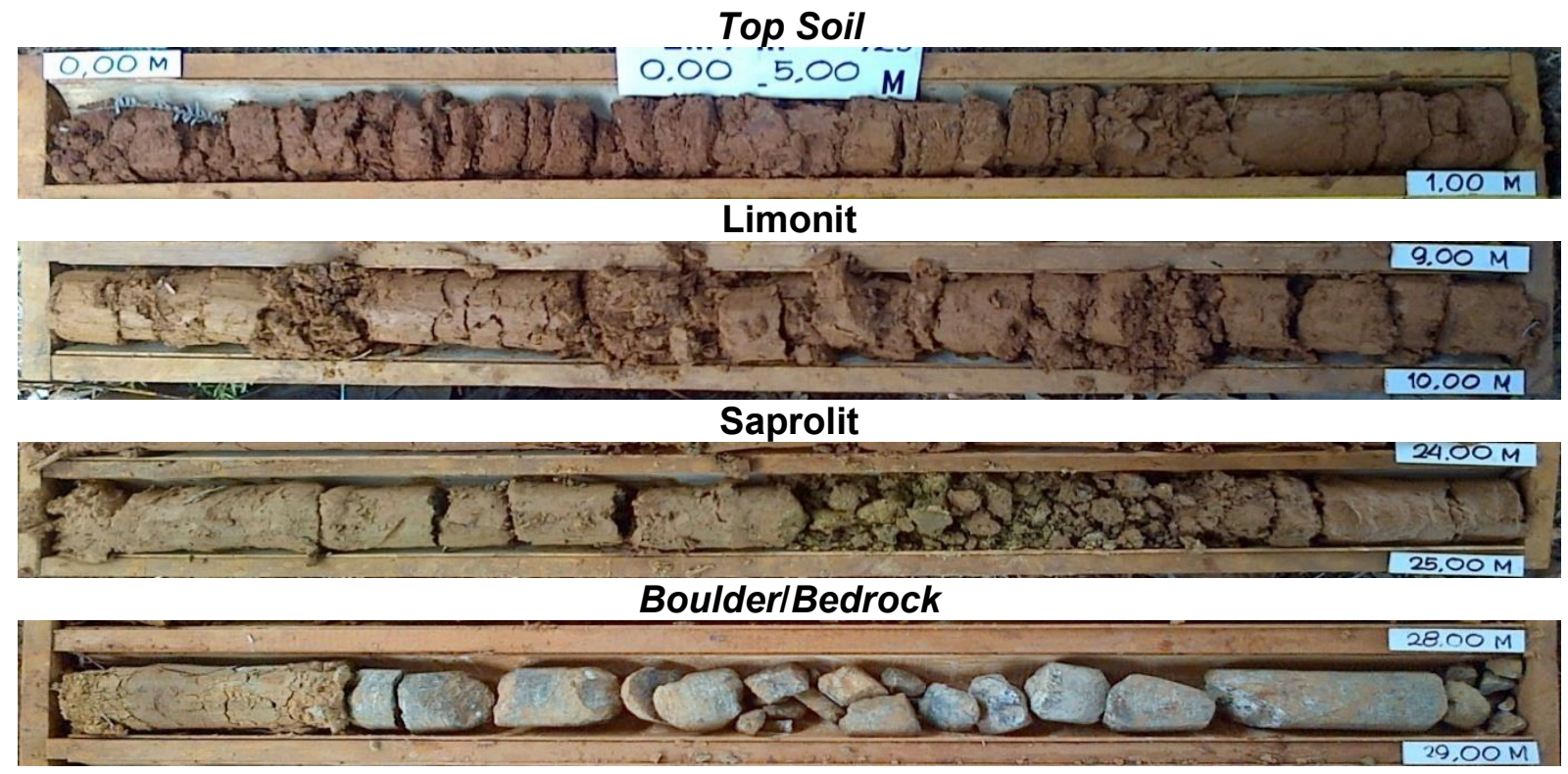

Gambar 5. Conto inti pemboran: A, lokasi HZ0204; B, lokasi DN0303

\section{Hasil pengolahan data analisis kimia}

Analisis kimia dengan metode XRF untuk 436 conto Blok $\mathrm{HZ}$ harzburgit dan 650 conto blok DN dunit menghasilkan 4 unsur major yaitu $\mathrm{Fe}, \mathrm{SiO}_{2}, \mathrm{MgO}, \mathrm{Al}_{2} \mathrm{O}_{3}$ dan 4 unsur minor yaitu $\mathrm{Ni}, \mathrm{Co}, \mathrm{MnO}, \mathrm{Cr}_{2} \mathrm{O}_{3}$.
Hasil analisis kimia tersebut digunakan dalam analisis statistik univariat (statistik deskriptif dan histogram) dan multivariat (analisis korelasi) untuk unsur major dan minor per zonasi laterit nikel. Masingmasing 4 unsur major dan minor dari Blok $\mathrm{HZ}$ dan DN tersebut di atas mempunyai nilai statistik deskriptif (mean, median, stDev, nilai minimum, nilai maksimum, 
skewness, kurtosis dan koefisien variasi), dan histogram untuk mengetahui distribusi data. Serta untuk mengetahui normal atau tidaknya distribusi data, dapat diketahui dari koefisien variasi sebagai berikut.

- Analsis statistik deskriptif

Untuk keseluruhan zona laterit nikel, hasil statistik deskriptif menunjukkan nilai standar deviasi yang relatif sedang pada unsur major namun relatif kecil pada unsur minor. Tetapi dilihat dari distribusi data melalui skewness dan kurtosis menunjukkan nilai yang bervariasi. Berdasarkan nilai koefisien variasi (CoefVar), ketika nilainya $>0,5$ maka data terdistribusi tidak normal sedangkan sebaliknya $(\leq 0,5)$ maka data terdistribusi normal (Tabel 1 dan Tabel 2.). Berdasarkan tabel tersebut, pada blok $H Z$, unsur-unsur yang terdistribusi tidak normal terdiri dari zona top soil ( $\mathrm{MgO}$, Co dan $\mathrm{MnO})$, limonit $\left(\mathrm{SiO}_{2}\right.$, $\mathrm{MgO}$, Co dan $\mathrm{MnO})$ dan saprolit $\left(\mathrm{Al}_{2} \mathrm{O}_{3}\right.$ dan (Co). Sementara pada blok DN terdiri dari zona top soil $\left(\mathrm{SiO}_{2}, \mathrm{Al}_{2} \mathrm{O}_{3}, \mathrm{Ni}\right.$, $\mathrm{Co}, \mathrm{MnO}$ dan $\left.\mathrm{Cr}_{2} \mathrm{O}_{3}\right)$, limonit $\left(\mathrm{SiO}_{2}\right.$, $\mathrm{MgO}$, Co dan $\mathrm{MnO})$, saprolit $\left(\mathrm{Cr}_{2} \mathrm{O}_{3}\right)$ dan bedrock $\left(\mathrm{Al}_{2} \mathrm{O}_{3}\right.$, Co dan $\left.\mathrm{MnO}\right)$. Maka untuk data yang terdistribusi normal pada Blok $\mathrm{HZ}$ secara umum terdiri dari unsur $\mathrm{Fe}, \mathrm{Ni}$ dan $\mathrm{Cr}_{2} \mathrm{O}_{3}$. Untuk per zona terdapat top soil $\left(\mathrm{SiO}_{2}\right.$ dan $\left.\mathrm{Al}_{2} \mathrm{O}_{3}\right)$ dan saprolit $\left(\mathrm{SiO}_{2}, \mathrm{MgO}\right.$ dan $\left.\mathrm{MnO}\right)$.

Tabel 1. Statistik deskriptif analisis kimia per zonasi laterit nikel Blok $\mathrm{HZ}$

\begin{tabular}{|c|c|c|c|c|c|c|c|c|c|c|c|c|}
\hline \multirow[b]{2}{*}{ Zona } & \multicolumn{2}{|c|}{ Variabel } & \multicolumn{9}{|c|}{ Parameter } & \multirow[b]{2}{*}{ Distribusi } \\
\hline & $\begin{array}{l}\text { Tipe } \\
\text { Unsur }\end{array}$ & Unsur & $\mathbf{N}$ & Mean & Median & StDev & $\begin{array}{c}\text { Minim } \\
\text { um }\end{array}$ & Maximum & Skewness & Kurtosis & CoefVar & \\
\hline \multirow{8}{*}{ Top Soil } & \multirow{4}{*}{ Major } & $\mathrm{Fe}$ & 11 & 41,97 & 42,03 & 2,67 & 37,97 & 45,61 & $-0,12$ & $-1,56$ & 0,06 & Normal \\
\hline & & $\mathrm{SiO}_{2}$ & 11 & 7,86 & 8,25 & 2,67 & 4,31 & 11,95 & 0,16 & $-1,20$ & 0,34 & Normal \\
\hline & & $\mathrm{MgO}$ & 11 & 2,25 & 1,80 & 1,27 & 1,14 & 5,25 & 1,46 & 2,05 & 0,57 & $\begin{array}{l}\text { Tidak } \\
\text { normal }\end{array}$ \\
\hline & & $\mathrm{Al}_{2} \mathrm{O}_{3}$ & 11 & 10,30 & 10,77 & 3,22 & 2,84 & 15,30 & $-1,03$ & 2,37 & 0,31 & Normal \\
\hline & \multirow{4}{*}{ Minor } & $\mathrm{Ni}$ & 11 & 1,22 & 1,19 & 0,32 & 0,66 & 1,67 & $-0,21$ & $-0,79$ & 0,26 & Normal \\
\hline & & Co & 11 & 0,15 & 0,10 & 0,11 & 0,05 & 0,39 & 1,23 & 0,52 & 0.75 & $\begin{array}{l}\text { Tidak } \\
\text { normal } \\
\end{array}$ \\
\hline & & $\mathrm{MnO}$ & 11 & 0,75 & 0,44 & 0,62 & 0,21 & 2,00 & 1,09 & $-0,13$ & 0,82 & $\begin{array}{l}\text { Tidak } \\
\text { normal }\end{array}$ \\
\hline & & $\mathrm{Cr}_{2} \mathrm{O}_{3}$ & 11 & 2,87 & 2,94 & 0,39 & 2,33 & 3,66 & 0,52 & 0,17 & 0,14 & Normal \\
\hline \multirow{8}{*}{ Limonit } & \multirow{4}{*}{ Major } & $\mathrm{Fe}$ & 90 & 38,99 & 38,75 & 6,57 & 22,53 & 50,57 & $-0,23$ & $-0,62$ & 0,17 & Normal \\
\hline & & $\mathrm{SiO}_{2}$ & 90 & 11,90 & 10,83 & 6,76 & 2,80 & 27,45 & 0,51 & $-0,80$ & 0,57 & $\begin{array}{l}\text { Tidak } \\
\text { normal }\end{array}$ \\
\hline & & $\mathrm{MgO}$ & 90 & 3,86 & 2,40 & 3,45 & 1,03 & 17,04 & 1,90 & 3,60 & 0,89 & $\begin{array}{l}\text { Tidak } \\
\text { normal }\end{array}$ \\
\hline & & $\mathrm{Al}_{2} \mathrm{O}_{3}$ & 90 & 8,81 & 8,32 & 4,47 & 0,85 & 21,97 & 0,61 & $-0,10$ & 0,51 & $\begin{array}{l}\text { Tidak } \\
\text { normal }\end{array}$ \\
\hline & \multirow{4}{*}{ Minor } & $\mathrm{Ni}$ & 90 & 1,42 & 1,28 & 0,58 & 0,49 & 2,92 & 0,80 & $-0,12$ & 0,41 & Normal \\
\hline & & Co & 90 & 0,15 & 0,12 & 0,11 & 0,04 & 0,65 & 2,64 & 8,76 & 0,73 & $\begin{array}{l}\text { Tidak } \\
\text { normal }\end{array}$ \\
\hline & & $\mathrm{MnO}$ & 90 & 0,99 & 0,78 & 0,71 & 0,17 & 3,28 & 1,34 & 1,58 & 0,72 & $\begin{array}{l}\text { Tidak } \\
\text { normal }\end{array}$ \\
\hline & & $\mathrm{Cr}_{2} \mathrm{O}_{3}$ & 90 & 2,59 & 2,49 & 0,66 & 1,37 & 4,87 & 0,84 & 0,80 & 0,26 & Normal \\
\hline \multirow{8}{*}{ Saprolit } & \multirow{4}{*}{ Major } & $\mathrm{Fe}$ & 188 & 13,47 & 12,01 & 4,95 & 6,90 & 29,08 & 1,11 & 0,47 & 0,37 & Normal \\
\hline & & $\mathrm{SiO}_{2}$ & 188 & 38,49 & 38,75 & 5,78 & 22,87 & 62,22 & 0,25 & 1,59 & 0,15 & Normal \\
\hline & & $\mathrm{MgO}$ & 188 & 22,66 & 23,77 & 6,37 & 4,72 & 35,14 & $-0,75$ & 0,11 & 0,28 & Normal \\
\hline & & $\mathrm{Al}_{2} \mathrm{O}_{3}$ & 188 & 2,11 & 1,85 & 1,20 & 0,29 & 7,15 & 1,29 & 2,27 & 0,57 & $\begin{array}{l}\text { Tidak } \\
\text { normal }\end{array}$ \\
\hline & \multirow{4}{*}{ Minor } & $\mathrm{Ni}$ & 188 & 1,71 & 1,53 & 0,79 & 0,60 & 4,04 & 0,54 & $-0,56$ & 0,46 & Normal \\
\hline & & Co & 188 & 0,04 & 0,03 & 0,02 & 0,01 & 0,12 & 1,64 & 3,09 & 0,58 & $\begin{array}{l}\text { Tidak } \\
\text { normal }\end{array}$ \\
\hline & & $\mathrm{MnO}$ & 188 & 0,27 & 0,24 & 0,11 & 0,13 & 0,63 & 1,23 & 1,09 & 0,39 & Normal \\
\hline & & $\mathrm{Cr}_{2} \mathrm{O}_{3}$ & 188 & 0,83 & 0,71 & 0,33 & 0,40 & 1,81 & 1,20 & 0,84 & 0,40 & Normal \\
\hline \multirow{8}{*}{$\begin{array}{l}\text { Boulderl } \\
\text { Bedrock }\end{array}$} & \multirow{4}{*}{ Major } & $\mathrm{Fe}$ & 147 & 7,07 & 6,76 & 1,04 & 5,58 & 10,66 & 1,21 & 1,06 & 0,15 & Normal \\
\hline & & $\mathrm{SiO}_{2}$ & 147 & 39,37 & 39,42 & 2,69 & 32,94 & 48,26 & 0,42 & 0,81 & 0,07 & Normal \\
\hline & & $\mathrm{MgO}$ & 147 & 33,53 & 33,81 & 3,23 & 23,74 & 40,82 & $-0,45$ & $-0,11$ & 0,10 & Normal \\
\hline & & $\mathrm{Al}_{2} \mathrm{O}_{3}$ & 147 & 1,02 & 1,07 & 0,40 & 0,23 & 2,54 & $-0,02$ & 1,04 & 0,39 & Normal \\
\hline & \multirow{4}{*}{ Minor } & $\mathrm{Ni}$ & 147 & 0,42 & 0,38 & 0,17 & 0,25 & 0,98 & 1,36 & 1,25 & 0,40 & Normal \\
\hline & & Co & 147 & 0,01 & 0,01 & 0,01 & 0,01 & 0,03 & 1,68 & 2,07 & 0,40 & Normal \\
\hline & & $\mathrm{MnO}$ & 147 & 0,14 & 0,13 & 0,03 & 0,07 & 0,36 & 2,60 & 14,77 & 0,24 & Normal \\
\hline & & $\mathrm{Cr}_{2} \mathrm{O}_{3}$ & 147 & 0,45 & 0,45 & 0,07 & 0,28 & 0,70 & 0,37 & 0,81 & 0,15 & Normal \\
\hline
\end{tabular}




\section{MAKALAH ILMIAH}

Tabel 2.Statistik deskriptif analisis kimia per zonasi laterit nikel Blok DN

\begin{tabular}{|c|c|c|c|c|c|c|c|c|c|c|c|c|}
\hline \multirow[b]{2}{*}{ Zona } & \multicolumn{2}{|c|}{ Variabel } & \multicolumn{9}{|c|}{ Parameter } & \multirow[b]{2}{*}{ Distribusi } \\
\hline & Tipe Unsur & Unsur & $\mathbf{N}$ & Mean & Median & StDev & $\begin{array}{l}\text { Mini } \\
\text { mum }\end{array}$ & $\begin{array}{c}\text { Maximu } \\
m\end{array}$ & Skewness & Kurtosis & CoefVar & \\
\hline \multirow{8}{*}{ Top Soil } & \multirow{4}{*}{ Major } & $\mathrm{Fe}$ & 23 & 37,71 & 42,35 & 9,38 & 23,02 & 49,29 & $-0,56$ & $-1,49$ & 0,25 & Normal \\
\hline & & $\mathrm{SiO}_{2}$ & 23 & 5,82 & 4,87 & 4,62 & 1,87 & 22,72 & 2,92 & 8,92 & 0,79 & $\begin{array}{l}\text { Tidak } \\
\text { normal }\end{array}$ \\
\hline & & $\mathrm{MgO}$ & 23 & 1,25 & 1,30 & 0,41 & 0,63 & 2,27 & 0,62 & 0,40 & 0,33 & Normal \\
\hline & & $\mathrm{Al}_{2} \mathrm{O}_{3}$ & 23 & 18,11 & 12,59 & 11,05 & 6,70 & 38,25 & 0,85 & $-0,93$ & 0,61 & $\begin{array}{l}\text { Tidak } \\
\text { normal } \\
\end{array}$ \\
\hline & \multirow{4}{*}{ Minor } & $\mathrm{Ni}$ & 23 & 0,81 & 0,90 & 0,45 & 0,12 & 1,67 & $-0,16$ & $-0,91$ & 0,56 & $\begin{array}{l}\text { Tidak } \\
\text { normal } \\
\end{array}$ \\
\hline & & Co & 23 & 0,06 & 0,06 & 0,04 & 0,02 & 0,20 & 1,98 & 5,40 & 0,62 & $\begin{array}{l}\text { Tidak } \\
\text { normal } \\
\end{array}$ \\
\hline & & $\mathrm{MnO}$ & 23 & 0,29 & 0,15 & 0,37 & 0,06 & 1,56 & 2,46 & 5,96 & 1,26 & $\begin{array}{l}\text { Tidak } \\
\text { normal }\end{array}$ \\
\hline & & $\mathrm{Cr}_{2} \mathrm{O}_{3}$ & 23 & 4,10 & 3,63 & 3,15 & 0,57 & 13,69 & 1,47 & 2,78 & 0,77 & $\begin{array}{l}\text { Tidak } \\
\text { normal } \\
\end{array}$ \\
\hline \multirow{8}{*}{ Limonit } & \multirow{4}{*}{ Major } & $\mathrm{Fe}$ & $\begin{array}{r}37 \\
1\end{array}$ & 42,79 & 43,57 & 5,92 & 20,26 & 53,79 & $-0,94$ & 1,10 & 0,14 & Normal \\
\hline & & $\mathrm{SiO}_{2}$ & $\begin{array}{r}37 \\
1 \\
\end{array}$ & 6,47 & 4,01 & 5,77 & 1,60 & 37,74 & 2,08 & 4,84 & 0,89 & $\begin{array}{l}\text { Tidak } \\
\text { normal }\end{array}$ \\
\hline & & $\mathrm{MgO}$ & $\begin{array}{r}37 \\
1 \\
\end{array}$ & 1,42 & 1,00 & 1,70 & 0,45 & 16,68 & 6,19 & 43,66 & 1,20 & $\begin{array}{l}\text { Tidak } \\
\text { normal } \\
\end{array}$ \\
\hline & & $\mathrm{Al}_{2} \mathrm{O}_{3}$ & $\begin{array}{r}37 \\
1 \\
\end{array}$ & 9,12 & 8,91 & 3,80 & 1,64 & 34,81 & 2,11 & 9,51 & 0,42 & Normal \\
\hline & \multirow{4}{*}{ Minor } & $\mathrm{Ni}$ & $\begin{array}{r}37 \\
1 \\
\end{array}$ & 1,42 & 1,39 & 0,50 & 0,19 & 3,48 & 0,85 & 2,12 & 0,35 & Normal \\
\hline & & Co & $\begin{array}{r}37 \\
1 \\
\end{array}$ & 0,13 & 0,11 & 0,08 & 0,03 & 0,58 & 1,82 & 5,13 & 0,58 & $\begin{array}{l}\text { Tidak } \\
\text { normal } \\
\end{array}$ \\
\hline & & $\mathrm{MnO}$ & $\begin{array}{r}37 \\
1 \\
\end{array}$ & 1,06 & 0,82 & 1,00 & 0,03 & 7,18 & 1,85 & 5,58 & 0,95 & $\begin{array}{l}\text { Tidak } \\
\text { normal } \\
\end{array}$ \\
\hline & & $\mathrm{Cr}_{2} \mathrm{O}_{3}$ & $\begin{array}{r}37 \\
1 \\
\end{array}$ & 3,37 & 3,06 & 1,47 & 1,01 & 11,18 & 1,92 & 5,65 & 0,44 & Normal \\
\hline \multirow{8}{*}{ Saprolit } & \multirow{4}{*}{ Major } & $\mathrm{Fe}$ & $\begin{array}{r}16 \\
3 \\
\end{array}$ & 15,40 & 14,38 & 5,03 & 7,14 & 31,16 & 0,92 & 0,38 & 0,33 & Normal \\
\hline & & $\mathrm{SiO}_{2}$ & $\begin{array}{r}16 \\
3 \\
\end{array}$ & 34,20 & 33,81 & 5,96 & 19,89 & 49,07 & $-0,08$ & 0,07 & 0,17 & Normal \\
\hline & & $\mathrm{MgO}$ & $\begin{array}{r}16 \\
3 \\
\end{array}$ & 19,35 & 19,46 & 6,09 & 2,62 & 33,12 & $-0,36$ & 0,29 & 0,31 & Normal \\
\hline & & $\mathrm{Al}_{2} \mathrm{O}_{3}$ & $\begin{array}{r}16 \\
3 \\
\end{array}$ & 2,74 & 2,45 & 1,16 & 0,52 & 7,57 & 1,17 & 1,47 & 0,42 & Normal \\
\hline & \multirow{4}{*}{ Minor } & $\mathrm{Ni}$ & $\begin{array}{r}16 \\
3 \\
\end{array}$ & 2,10 & 1,93 & 0,86 & 0,69 & 4,20 & 0,56 & $-0,63$ & 0,41 & Normal \\
\hline & & Co & $\begin{array}{r}16 \\
3 \\
\end{array}$ & 0,04 & 0,03 & 0,02 & 0,01 & 0,11 & 1,13 & 1,79 & 0,45 & Normal \\
\hline & & $\mathrm{MnO}$ & $\begin{array}{r}16 \\
3 \\
\end{array}$ & 0,35 & 0,29 & 0,20 & 0,12 & 1,49 & 2,60 & 9,30 & 0,56 & $\begin{array}{l}\text { Tidak } \\
\text { normal }\end{array}$ \\
\hline & & $\mathrm{Cr}_{2} \mathrm{O}_{3}$ & $\begin{array}{r}16 \\
3 \\
\end{array}$ & 0,97 & 0,84 & 0,39 & 0,43 & 2,61 & 1,32 & 1,62 & 0,40 & Normal \\
\hline \multirow{8}{*}{$\begin{array}{l}\text { Boulder } \\
\text { / } \\
\text { Bedrock }\end{array}$} & \multirow{4}{*}{ Major } & $\mathrm{Fe}$ & 93 & 7,77 & 7,13 & 2,01 & 5,43 & 15,48 & 1,76 & 3,02 & 0,26 & Normal \\
\hline & & $\mathrm{SiO}_{2}$ & 93 & 38,35 & 37,10 & 5,33 & 28,70 & 63,36 & 2,07 & 6,15 & 0,14 & Normal \\
\hline & & $\mathrm{MgO}$ & 93 & 31,20 & 33,00 & 6,55 & 0,52 & 40,45 & $-1,59$ & 4,05 & 0,21 & Normal \\
\hline & & $\mathrm{Al}_{2} \mathrm{O}_{3}$ & 93 & 1,32 & 1,22 & 0,81 & 0,20 & 4,99 & 2,12 & 6,82 & 0,62 & $\begin{array}{l}\text { Tidak } \\
\text { normal } \\
\end{array}$ \\
\hline & \multirow{4}{*}{ Minor } & $\mathrm{Ni}$ & 93 & 0,45 & 0,39 & 0,18 & 0,24 & 1,03 & 1,00 & 0,40 & 0,40 & Normal \\
\hline & & Co & 93 & 0,01 & 0,01 & 0,01 & 0,01 & 0,10 & 5,96 & 45,35 & 0,78 & $\begin{array}{l}\text { Tidak } \\
\text { normal } \\
\end{array}$ \\
\hline & & $\mathrm{MnO}$ & 93 & 0,15 & 0,13 & 0,10 & 0,07 & 1,02 & 6,89 & 58,02 & 0,69 & $\begin{array}{l}\text { Tidak } \\
\text { normal } \\
\end{array}$ \\
\hline & & $\mathrm{Cr}_{2} \mathrm{O}_{3}$ & 93 & 0,51 & 0,48 & 0,12 & 0,29 & 1,00 & 1,52 & 3,78 & 0,23 & Normal \\
\hline
\end{tabular}




\section{MAKALAH ILMIAH}

Sedangkan pada blok DN secara umum hanya unsur $\mathrm{Fe}$. Untuk per zona terdapat top soil $(\mathrm{MgO})$, limonit $\left(\mathrm{Al}_{2} \mathrm{O}_{3}\right.$, $\mathrm{Ni}$ dan $\left.\mathrm{Cr}_{2} \mathrm{O}_{3}\right)$, saprolit $\left(\mathrm{SiO}_{2}, \mathrm{MgO}\right.$ $\mathrm{Al}_{2} \mathrm{O}_{3}, \quad \mathrm{Ni}$, Co dan $\mathrm{MnO}$ ) dan boulderlbedrock $\left(\mathrm{SiO}_{2}, \mathrm{MgO}, \mathrm{Ni}\right.$ dan $\mathrm{Cr}_{2} \mathrm{O}_{3}$ ).

- Analisis histogram

Histogram menginterpretasikan distribusi kecondongan/skewness serta kelengkungan/ kurtosis data. Pada bentuk skewness, data yang terdisribusi normal berbentuk simetris dan memiliki nilai kecondongan mendekati nol dengan nilai rata-rata/mean, median dan modus/mode memiliki nilai yang relatif mirip. Sementara data yang

\section{Histogram Fe}

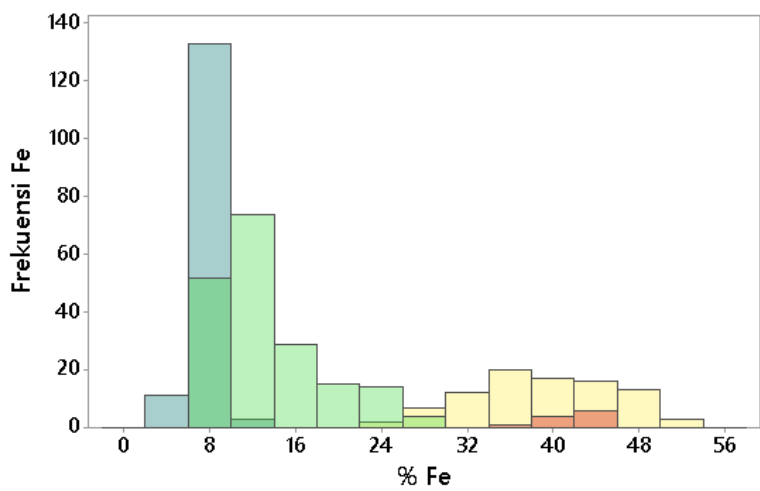

Histogram MgO

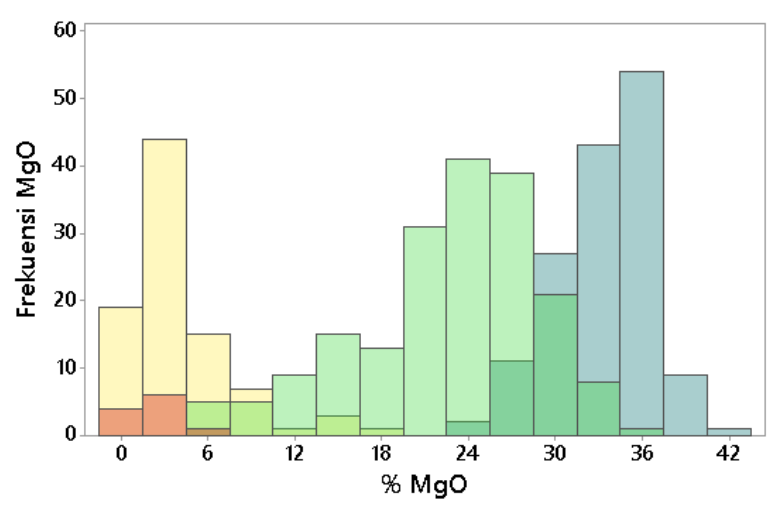

condong ke kiri memiliki nilai kecondongan negatif dengan nilai ratarata dan median di bawah nilai modus. Data yang condong ke kanan memiliki nilai kecondongan positif dengan nilai rata-rata dan median di atas nilai modus. Adapun berdasarkan kurtosis, nilai kelengkungan yang mendekati nol adalah lengkungan normal. Apabila nilai positif semakin tinggi maka semakin menajam lengkungannya. Apabila nilai negatif semakin tinggi maka semakin menumpul lengkungannya (Sinclair etc, 2004). Data hasil analisis kimia Blok HZ dan Blok DN direpresentasikan dalam bentuk histogram pada Gambar 6 dan Gambar 7.

Histogram $\mathrm{SiO}_{2}$

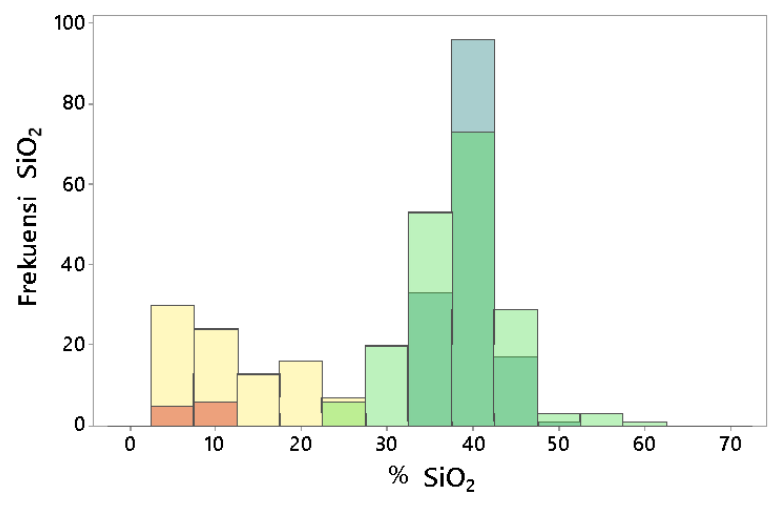

Histogram $\mathrm{A}_{12} \mathrm{O}_{3}$

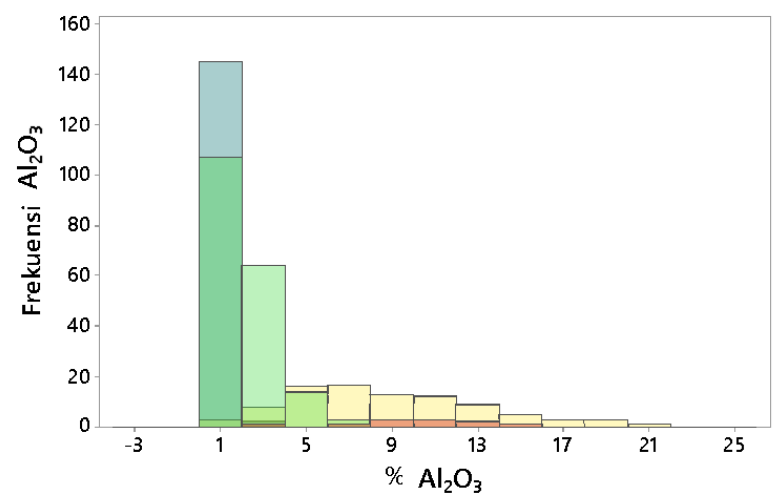




\section{MAKALAH ILMIAH}

Histogram Ni

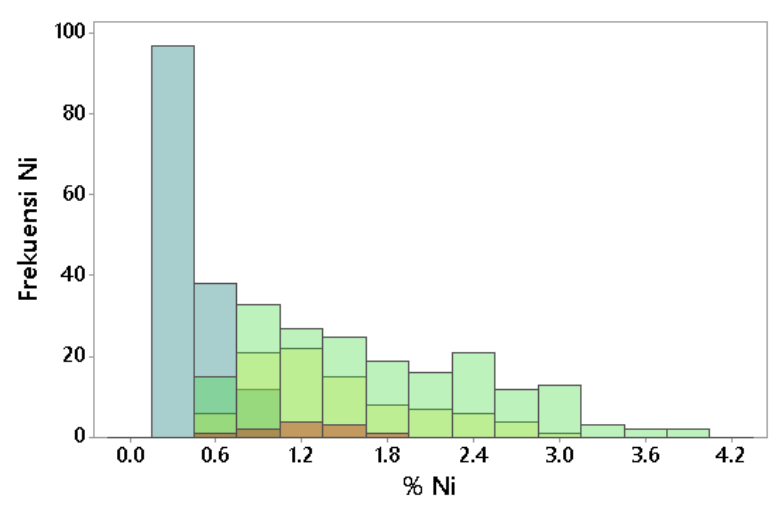

Histogram MnO

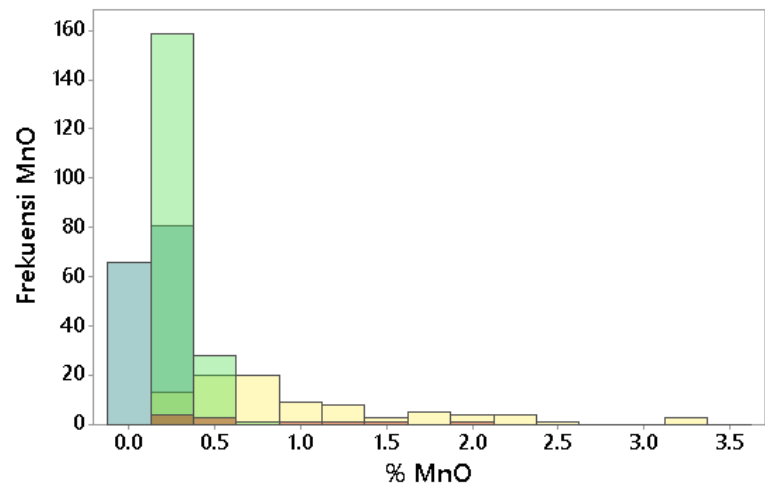

Keterangan :

Top Soil Limonit Saprolit

Gambar 6.Grafik histogram unsur major dan minor Blok HZ

\section{Histogram Fe}

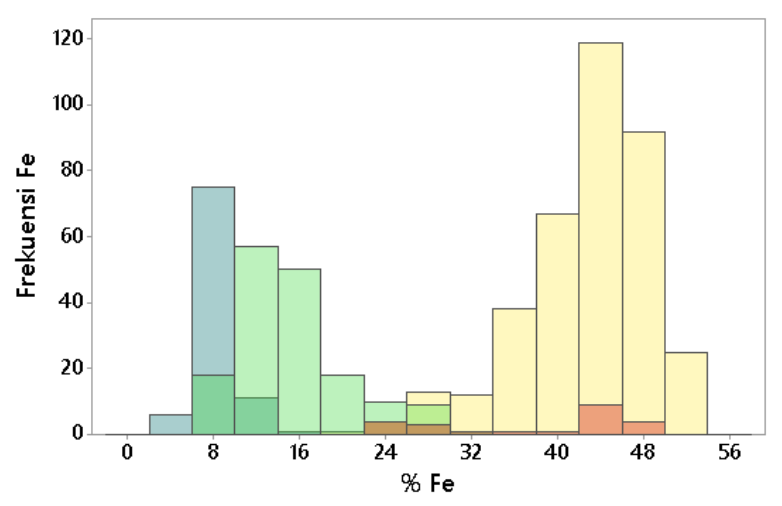

Boulder/Bedrock

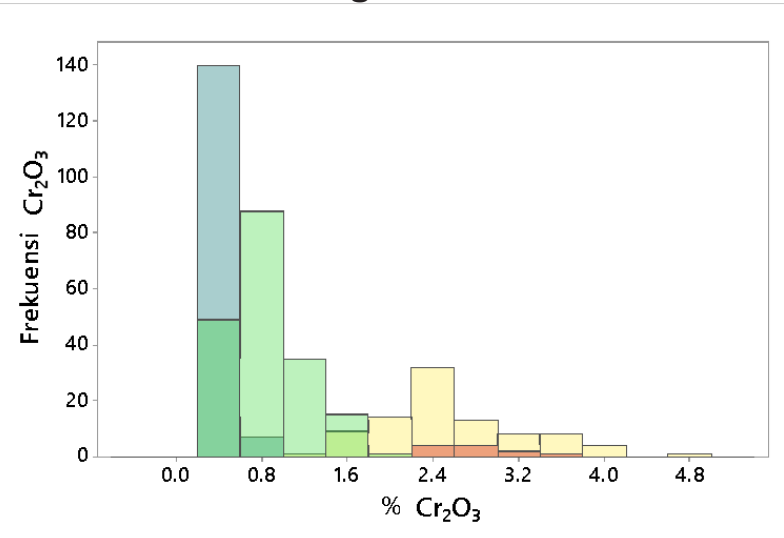

Histogram Co

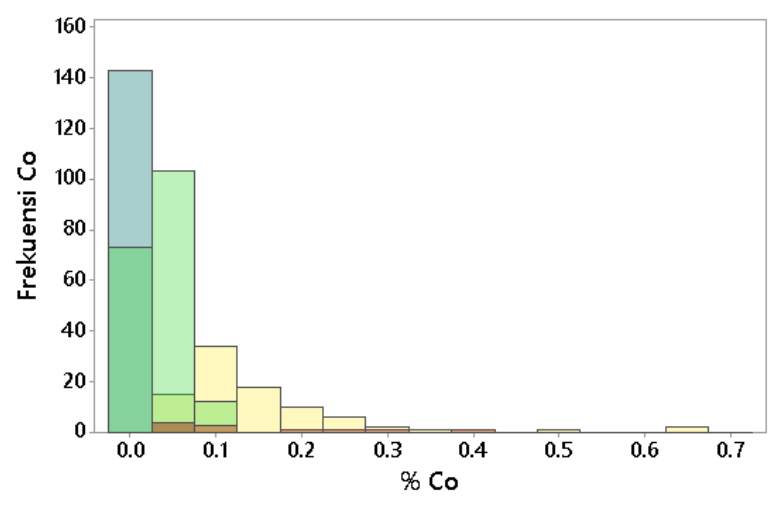

Histogram $\mathrm{Cr}_{2} \mathrm{O}_{3}$ 
Histogram MgO

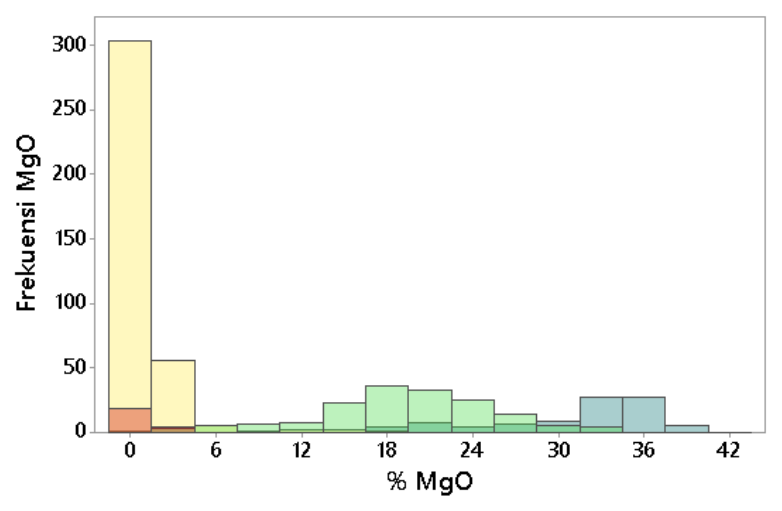

Histogram Ni

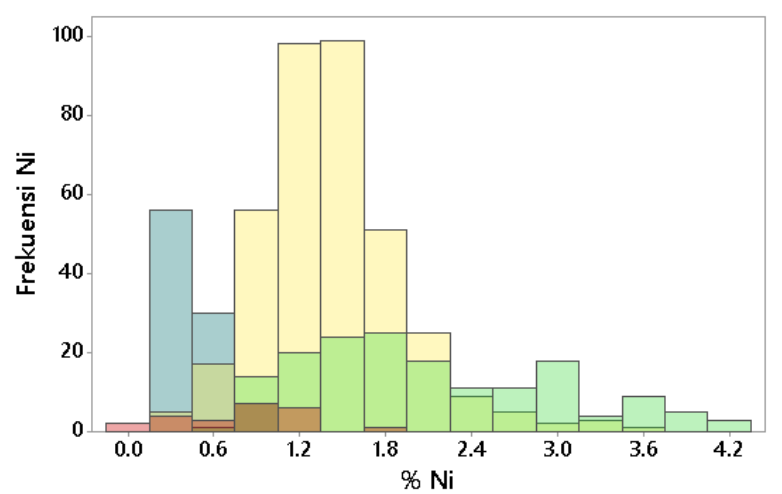

Histogram MnO

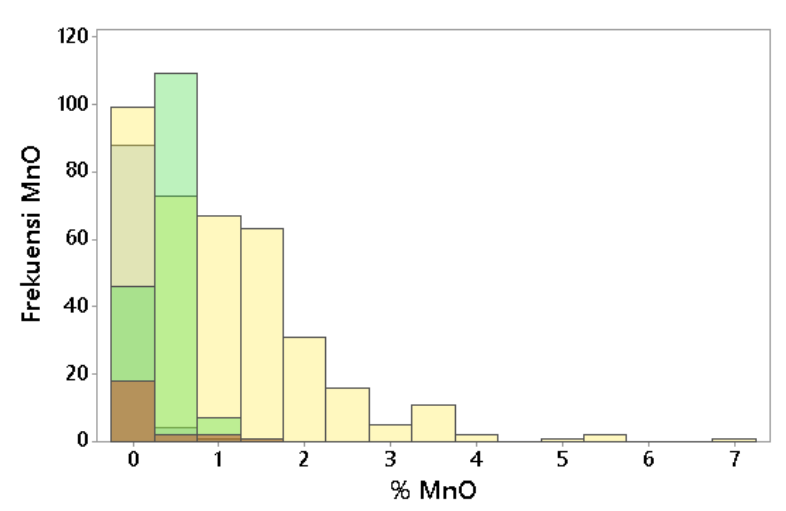

Keterangan : Top Soil Limonit Saprolit

Gambar 7. Grafik histogram unsur major dan minor Blok DN

Adapun analisis multivariat terhadap keseluruhan maupun masing-masing zona laterit nikel menerapkan korelasi unsur kimia major dan minor, berdasarkan koefisien korelasi dengan kisaran nilai - 1 $<r<+1$ (Tabel 3). Berdasarkan klasifikasi
Histogram $\mathrm{A}_{12} \mathrm{O}_{3}$

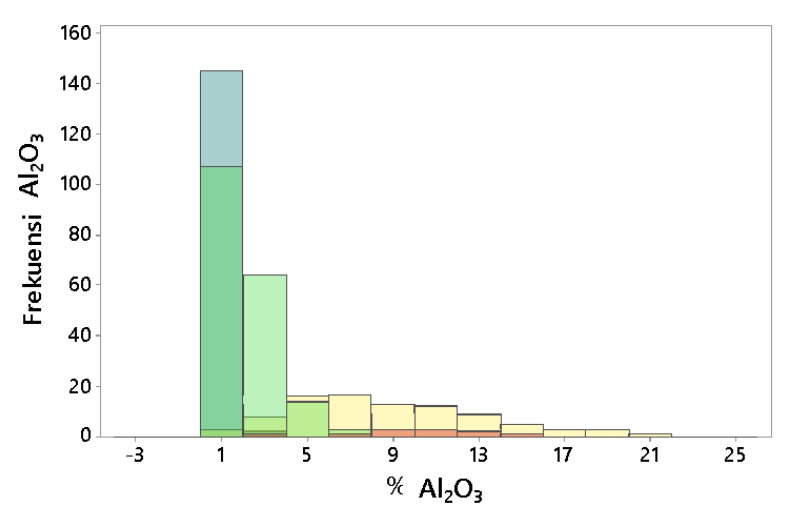

\section{Histogram Co}

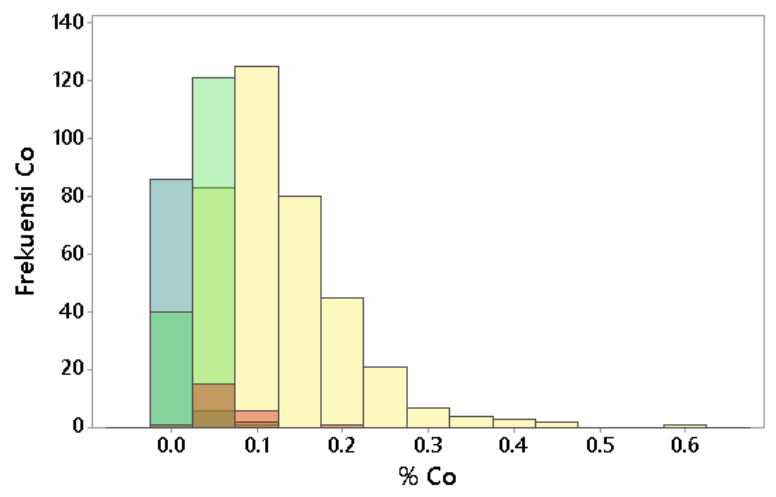

Histogram $\mathrm{Cr}_{2} \mathrm{O}_{3}$

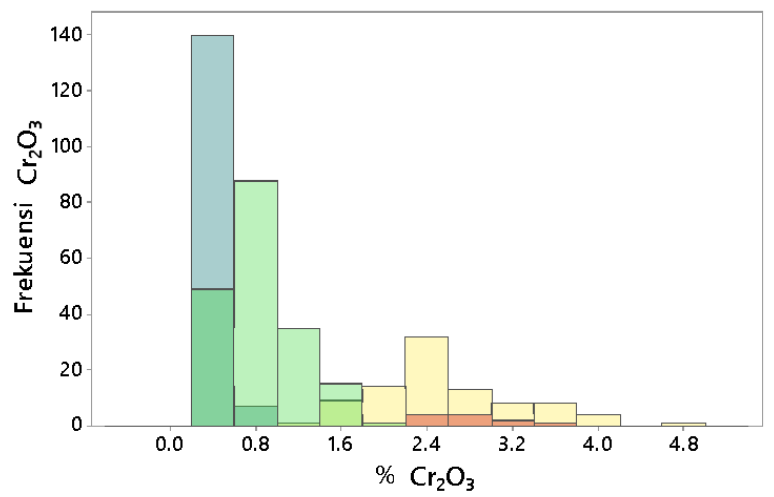

Boulder/Bedrock koefisien korelasi, tingkat korelasi kuat hingga sangat kuat pada angka korelasi negatif maupun positif pada unsur major dan minor digunakan untuk mengetahui unsur-unsur yang dapat berkontribusi sebagai penyusun zona laterit nikel. 
Korelasi tersebut diklasifikasikan pada Tabel 4 untuk Blok $\mathrm{HZ}$ dan Tabel 5 untuk Blok DN.

Unsur-unsur berkorelasi kuat hingga sangat kuat tersebut dapat diasumsikan memiliki hubungan asosiasi dan resistensi unsur yang sangat kuat dan dapat terlihat sehingga berkontribusi dalam penyusunan zonasi laterit nikel. Berikut korelasi unsur major dan minor Blok HZ dan DN.

Tabel 3. Tabel koefisien korelasi kandungan unsur major dan minor pada Blok $\mathrm{HZ}$ dan DN

\begin{tabular}{|c|c|c|c|c|c|c|c|c|c|c|c|c|c|c|c|c|c|c|}
\hline Zona & \multicolumn{9}{|c|}{ Blok HZ } & \multicolumn{9}{|c|}{ Blok DN } \\
\hline \multirow{9}{*}{$\begin{array}{l}\text { Semua } \\
\text { Zona }\end{array}$} & & $\mathrm{Fe}$ & $\mathrm{SiO}_{2}$ & $\mathrm{MgO}$ & $\mathrm{Al}_{2} \mathrm{O}_{3}$ & $\mathrm{Ni}$ & Co & $\mathrm{MnO}$ & $\mathrm{Cr}_{2} \mathrm{O}_{3}$ & & $\mathrm{Fe}$ & $\mathrm{SiO}_{2}$ & $\mathrm{MgO}$ & $\mathrm{Al}_{2} \mathrm{O}_{3}$ & $\mathrm{Ni}$ & Co & $\mathrm{MnO}$ & $\mathrm{Cr}_{2} \mathrm{O}_{3}$ \\
\hline & $\mathrm{Fe}$ & 1,00 & $-0,94$ & $-0,94$ & 0,79 & 0,30 & 0,74 & 0,72 & $\begin{array}{r}0,95 \\
0,95\end{array}$ & $\mathrm{Fe}$ & 1,00 & $-0,96$ & $-0,93$ & 0,55 & 0,03 & 0,62 & 0,37 & 0,70 \\
\hline & $\mathrm{SiO}_{2}$ & $-0,94$ & 1,00 & 0,81 & $-0,79$ & $-0,19$ & $-0,70$ & $-0,68$ & $-0,91$ & $\mathrm{SiO}_{2}$ & $-0,96$ & 1,00 & 0,87 & $-0,68$ & 0,05 & $-0,61$ & $-0,38$ & $-0,72$ \\
\hline & $\mathrm{MgO}$ & $-0,94$ & 0,81 & 1,00 & $-0,81$ & $-0,43$ & $-0,68$ & $-0,66$ & $-0,90$ & $\mathrm{MgO}$ & $-0,93$ & 0,87 & 1,00 & $-0,67$ & $-0,16$ & $-0,63$ & $-0,42$ & $-0,69$ \\
\hline & $\mathrm{Al}_{2} \mathrm{O}_{3}$ & 0,79 & $-0,79$ & $-0,81$ & 1,00 & 0,10 & 0,48 & 0,45 & 0,76 & $\mathrm{Al}_{2} \mathrm{O}_{3}$ & 0,55 & $-0,68$ & $-0,67$ & 1,00 & $-0,17$ & 0,35 & 0,23 & 0,56 \\
\hline & $\mathrm{Ni}$ & 0,30 & $-0,19$ & $-0,43$ & 0,10 & 1,00 & 0,28 & 0,24 & 0,32 & $\mathrm{Ni}$ & 0,03 & 0,05 & $-0,16$ & $-0,17$ & 1,00 & 0,15 & 0,19 & $-0,01$ \\
\hline & Co & 0,74 & $-0,70$ & $-0,68$ & 0,48 & 0,28 & 1,00 & 0,92 & 0,72 & Co & 0,62 & $-0,61$ & $-0,63$ & 0,35 & 0,15 & 1,00 & 0,89 & 0,41 \\
\hline & MnO & 0,72 & $-0,68$ & $-0,66$ & 0,45 & 0,24 & 0,92 & 1,00 & 0,69 & $\mathrm{MnO}$ & 0,37 & $-0,38$ & $-0,42$ & 0,23 & 0,19 & 0,89 & 1,00 & 0,24 \\
\hline & $\mathrm{Cr}_{2} \mathrm{O}_{3}$ & 0,95 & $-0,91$ & $-0,90$ & 0,76 & 0,32 & 0,72 & 0,69 & 1,00 & $\mathrm{Cr}_{2} \mathrm{O}_{3}$ & 0,70 & $-0,72$ & $-0,69$ & 0,56 & $-0,01$ & 0,41 & 0,24 & 1,00 \\
\hline \multirow{9}{*}{ Top Soil } & & $\mathrm{Fe}$ & $\mathrm{SiO}_{2}$ & MgO & $\mathrm{Al}_{2} \mathrm{O}_{3}$ & $\mathrm{Ni}$ & Co & $\mathrm{MnO}$ & $\mathrm{Cr}_{2} \mathrm{O}_{3}$ & & $\mathrm{Fe}$ & $\mathrm{SiO}_{2}$ & MgO & $\mathrm{Al}_{2} \mathrm{O}_{3}$ & $\mathrm{Ni}$ & Co & $\mathrm{MnO}$ & $\mathrm{Cr}_{2} \mathrm{O}_{3}$ \\
\hline & $\mathrm{Fe}$ & 1,00 & $-0,82$ & 0,21 & $-0,44$ & 0,06 & $-0,33$ & $-0,33$ & 0,13 & $\mathrm{Fe}$ & 1,00 & $-0,27$ & 0,38 & $-0,88$ & 0,83 & 0,61 & 0,34 & 0,24 \\
\hline & $\mathrm{SiO}_{2}$ & $-0,82$ & 1,00 & 0,33 & $-0,14$ & 0,33 & 0,68 & 0,70 & $-0,38$ & $\mathrm{SiO}_{2}$ & $-0,27$ & 1,00 & 0,08 & $-0,08$ & $-0,09$ & $-0,12$ & $-0,05$ & $-0,10$ \\
\hline & $\mathrm{MgO}$ & 0,21 & 0,33 & 1,00 & $-0,80$ & 0,45 & 0,48 & 0,51 & $-0,60$ & MgO & 0,38 & 0,08 & 1,00 & $-0,55$ & 0,51 & 0,39 & 0,26 & 0,15 \\
\hline & $\mathrm{Al}_{2} \mathrm{O}_{3}$ & $-0,44$ & $-0,14$ & $-0,80$ & 1,00 & $-0,73$ & $-0,57$ & $-0,59$ & 0,24 & $\mathrm{Al}_{2} \mathrm{O}_{3}$ & $-0,88$ & $-0,08$ & $-0,55$ & 1,00 & $-0,91$ & $-0,60$ & $-0,37$ & $-0,25$ \\
\hline & $\mathrm{Ni}$ & 0,06 & 0,33 & 0,45 & $-0,73$ & 1,00 & 0,78 & 0,79 & 0,20 & $\mathrm{Ni}$ & 0,83 & $-0,09$ & 0,51 & $-0,91$ & 1,00 & 0,75 & 0,60 & 0,24 \\
\hline & Co & $-0,33$ & 0,68 & 0,48 & $-0,57$ & 0,78 & 1,00 & 1,00 & $-0,16$ & Co & 0,61 & $-0,12$ & 0,39 & $-0,60$ & 0,75 & 1,00 & 0,92 & 0,02 \\
\hline & Mno & $-0,33$ & 0,70 & 0,51 & $-0,59$ & 0,79 & 1,00 & 1,00 & $-0,18$ & Mno & 0,34 & $-0,05$ & 0,26 & $-0,37$ & 0,60 & 0,92 & 1,00 & $-0,10$ \\
\hline & $\mathrm{Cr}_{2} \mathrm{O}_{3}$ & 0,13 & $-0,38$ & $-0,60$ & 0,24 & 0,20 & $-0,16$ & $-0,18$ & 1,00 & $\mathrm{Cr}_{2} \mathrm{O}_{3}$ & 0,24 & $-0,10$ & 0,15 & $-0,25$ & 0,24 & 0,02 & $-0,10$ & 1,00 \\
\hline \multirow{9}{*}{ Limonit } & & $\mathrm{Fe}$ & $\mathrm{SiO}_{2}$ & MgO & $\mathrm{Al}_{2} \mathrm{O}_{3}$ & $\mathrm{Ni}$ & Co & MnO & $\mathrm{Cr}_{2} \mathrm{O}_{3}$ & & $\mathrm{Fe}$ & $\mathrm{SiO}_{2}$ & MgO & $\mathrm{Al}_{2} \mathrm{O}_{3}$ & $\mathrm{Ni}$ & Co & MnO & $\mathrm{Cr}_{2} \mathrm{O}_{3}$ \\
\hline & $\mathrm{Fe}$ & 1,00 & $-0,93$ & $-0,65$ & $-0,07$ & $-0,29$ & 0,30 & 0,33 & 0,54 & $\mathrm{Fe}$ & 1,00 & $-0,81$ & $-0,49$ & $-0,33$ & $-0,33$ & $-0,06$ & $-0,20$ & 0,10 \\
\hline & $\mathrm{SiO}_{2}$ & $-0,93$ & 1,00 & 0,72 & $-0,19$ & 0,37 & $-0,27$ & $-0,31$ & $-0,56$ & $\mathrm{SiO}_{2}$ & $-0,81$ & 1,00 & 0,50 & $-0,18$ & 0,48 & $-0,02$ & 0,07 & $-0,23$ \\
\hline & $\mathrm{MgO}$ & $-0,65$ & 0,72 & 1,00 & $-0,49$ & 0,56 & $-0,13$ & $-0,16$ & $-0,42$ & MgO & $-0,49$ & 0,50 & 1,00 & $-0,23$ & 0,38 & $-0,12$ & $-0,02$ & $-0,13$ \\
\hline & $\mathrm{Al}_{2} \mathrm{O}_{3}$ & $-0,07$ & $-0,19$ & $-0,49$ & 1,00 & $-0,68$ & $-0,29$ & $-0,31$ & $-0,12$ & $\mathrm{Al}_{2} \mathrm{O}_{3}$ & $-0,33$ & $-0,18$ & $-0,23$ & 1,00 & $-0,41$ & $-0,07$ & $-0,02$ & 0,21 \\
\hline & $\mathrm{Ni}$ & $-0,29$ & 0,37 & 0,56 & $-0,68$ & 1,00 & 0,20 & 0,13 & 0,14 & $\mathrm{Ni}$ & $-0,33$ & 0,48 & 0,38 & $-0,41$ & 1,00 & 0,26 & 0,30 & $-0,10$ \\
\hline & Co & 0,30 & $-0,27$ & $-0,13$ & $-0,29$ & 0,20 & 1,00 & 0,84 & 0,22 & Co & $-0,06$ & $-0,02$ & $-0,12$ & $-0,07$ & 0,26 & 1,00 & 0,89 & $-0,09$ \\
\hline & MnO & 0,33 & $-0,31$ & $-0,16$ & $-0,31$ & 0,13 & 0,84 & 1,00 & 0,22 & Mno & $-0,20$ & 0,07 & $-0,02$ & $-0,02$ & 0,30 & 0,89 & 1,00 & $-0,09$ \\
\hline & $\mathrm{Cr}_{2} \mathrm{O}_{3}$ & 0,54 & $-0,56$ & $-0,42$ & $-0,12$ & 0,14 & 0,22 & 0,22 & 1,00 & $\mathrm{Cr}_{2} \mathrm{O}_{3}$ & 0,10 & $-0,23$ & $-0,13$ & 0,21 & $-0,10$ & $-0,09$ & $-0,09$ & 1,00 \\
\hline \multirow{9}{*}{ Saprolit } & & $\mathrm{Fe}$ & $\mathrm{SiO}_{2}$ & MgO & $\mathrm{Al}_{2} \mathrm{O}_{3}$ & $\mathrm{Ni}$ & Co & MnO & $\mathrm{Cr}_{2} \mathrm{O}_{3}$ & & $\mathrm{Fe}$ & $\mathrm{SiO}_{2}$ & $\mathrm{MgO}$ & $\mathrm{Al}_{2} \mathrm{O}_{3}$ & $\mathrm{Ni}$ & Co & $\mathrm{MnO}$ & $\mathrm{Cr}_{2} \mathrm{O}_{3}$ \\
\hline & $\mathrm{Fe}$ & 1,00 & $-0,65$ & $-0,86$ & 0,74 & 0,35 & 0,88 & 0,94 & 0,88 & $\mathrm{Fe}$ & 1,00 & $-0,77$ & $-0,85$ & 0,89 & 0,34 & 0,92 & 0,66 & 0,92 \\
\hline & $\mathrm{SiO}_{2}$ & $-0,65$ & 1,00 & 0,26 & $-0,39$ & $-0,45$ & $-0,64$ & $-0,58$ & $-0,64$ & $\mathrm{SiO}_{2}$ & $-0,77$ & 1,00 & 0,41 & $-0,72$ & $-0,29$ & $-0,70$ & $-0,39$ & $-0,78$ \\
\hline & $\mathrm{MgO}$ & $-0,86$ & 0,26 & 1,00 & $-0,79$ & $-0,34$ & $-0,70$ & $-0,79$ & $-0,78$ & $\mathrm{MgO}$ & $-0,85$ & 0,41 & 1,00 & $-0,78$ & $-0,42$ & $-0,79$ & $-0,64$ & $-0,75$ \\
\hline & $\mathrm{Al}_{2} \mathrm{O}_{3}$ & 0,74 & $-0,39$ & $-0,79$ & 1,00 & 0,24 & 0,59 & 0,72 & 0,79 & $\mathrm{Al}_{2} \mathrm{O}_{3}$ & 0,89 & $-0,72$ & $-0,78$ & 1,00 & 0,31 & 0,85 & 0,63 & 0,91 \\
\hline & $\mathrm{Ni}$ & 0,35 & $-0,45$ & $-0,34$ & 0,24 & 1,00 & 0,43 & 0,28 & 0,44 & $\mathrm{Ni}$ & 0,34 & $-0,29$ & $-0,42$ & 0,31 & 1,00 & 0,30 & 0,24 & 0,34 \\
\hline & Co & 0,88 & $-0,64$ & $-0,70$ & 0,59 & 0,43 & 1,00 & 0,87 & 0,81 & Co & 0,92 & $-0,70$ & $-0,79$ & 0,85 & 0,30 & 1,00 & 0,76 & 0,82 \\
\hline & MnO & 0,94 & $-0,58$ & $-0,79$ & 0,72 & 0,28 & 0,87 & 1,00 & 0,83 & MnO & 0,66 & $-0,39$ & $-0,64$ & 0,63 & 0,24 & 0,76 & 1,00 & 0,57 \\
\hline & $\mathrm{Cr}_{2} \mathrm{O}_{3}$ & 0,88 & $-0,64$ & $-0,78$ & 0,79 & 0,44 & 0,81 & 0,83 & 1,00 & $\mathrm{Cr}_{2} \mathrm{O}_{3}$ & 0,92 & $-0,78$ & $-0,75$ & 0,91 & 0,34 & 0,82 & 0,57 & 1,00 \\
\hline \multirow{9}{*}{$\begin{array}{l}\text { Boulderl } \\
\text { Bedrock }\end{array}$} & & $\mathrm{Fe}$ & $\mathrm{SiO}_{2}$ & MgO & $\mathrm{Al}_{2} \mathrm{O}_{3}$ & $\mathrm{Ni}$ & Co & $\mathrm{MnO}$ & $\mathrm{Cr}_{2} \mathrm{O}_{3}$ & & $\mathrm{Fe}$ & $\mathrm{SiO}_{2}$ & MgO & $\mathrm{Al}_{2} \mathrm{O}_{3}$ & $\mathrm{Ni}$ & Co & $\mathrm{MnO}$ & $\mathrm{Cr}_{2} \mathrm{O}_{3}$ \\
\hline & $\mathrm{Fe}$ & 1,00 & 0,41 & $-0,74$ & 0,27 & 0,52 & 0,80 & 0,75 & 0,58 & $\mathrm{Fe}$ & 1,00 & 0,30 & $-0,82$ & 0,75 & 0,51 & 0,79 & 0,70 & 0,89 \\
\hline & $\mathrm{SiO}_{2}$ & 0,41 & 1,00 & $-0,68$ & 0,16 & 0,23 & 0,26 & 0,39 & 0,33 & $\mathrm{SiO}_{2}$ & 0,30 & 1,00 & $-0,63$ & 0,12 & 0,04 & 0,47 & 0,54 & 0,25 \\
\hline & $\mathrm{MgO}$ & $-0,74$ & $-0,68$ & 1,00 & $-0,43$ & $-0,42$ & $-0,47$ & $-0,44$ & $-0,59$ & $\mathrm{MgO}$ & $-0,82$ & $-0,63$ & 1,00 & $-0,63$ & $-0,31$ & $-0,72$ & $-0,66$ & $-0,75$ \\
\hline & $\mathrm{Al}_{2} \mathrm{O}_{3}$ & 0,27 & 0,16 & $-0,43$ & 1,00 & 0,15 & 0,07 & 0,24 & 0,61 & $\mathrm{Al}_{2} \mathrm{O}_{3}$ & 0,75 & 0,12 & $-0,63$ & 1,00 & 0,36 & 0,65 & 0,60 & 0,80 \\
\hline & $\mathrm{Ni}$ & 0,52 & 0,23 & $-0,42$ & 0,15 & 1,00 & 0,40 & 0,38 & 0,51 & $\mathrm{Ni}$ & 0,51 & 0,04 & $-0,31$ & 0,36 & 1,00 & 0,31 & 0,30 & 0,40 \\
\hline & Co & 0,80 & 0,26 & $-0,47$ & 0,07 & 0,40 & 1,00 & 0,68 & 0,45 & Co & 0,79 & 0,47 & $-0,72$ & 0,65 & 0,31 & 1,00 & 0,96 & 0,72 \\
\hline & Mno & 0,75 & 0,39 & $-0,44$ & 0,24 & 0,38 & 0,68 & 1,00 & 0,49 & Mno & 0,70 & 0,54 & $-0,66$ & 0,60 & 0,30 & 0,96 & 1,00 & 0,66 \\
\hline & $\mathrm{Cr}_{2} \mathrm{O}_{3}$ & 0,58 & 0,33 & $-0,59$ & 0,61 & 0,51 & 0,45 & 0,49 & 1,00 & $\mathrm{Cr}_{2} \mathrm{O}_{3}$ & 0,89 & 0,25 & $-0,75$ & 0,80 & 0,40 & 0,72 & 0,66 & 1,00 \\
\hline
\end{tabular}




\section{MAKALAH ILMIAH}

Tabel 4. Tabel klasifikasi koefisien korelasi hasil analisis multivariat Blok HZ

\begin{tabular}{|c|c|c|c|c|c|c|c|}
\hline \multirow{2}{*}{$\begin{array}{c}\text { Angka } \\
\text { Korelasi }\end{array}$} & \multirow{2}{*}{$\begin{array}{l}\text { Tingkat } \\
\text { Korelasi }\end{array}$} & \multirow{2}{*}{$\begin{array}{l}\text { Tipe Unsur } \\
\text { Korelasi }\end{array}$} & \multicolumn{5}{|c|}{ Kategori Korelasi Zonasi } \\
\hline & & & $\begin{array}{c}\text { Semua } \\
\text { Zona }\end{array}$ & Top Soil & Limonite & Saprolite & $\begin{array}{l}\text { Boulderl } \\
\text { Bedrock }\end{array}$ \\
\hline \multirow{7}{*}{ Positif } & \multirow{3}{*}{ Sangat Kuat } & Major vs Major & $\begin{array}{c}\mathrm{SiO}_{2} \text { VS } \\
\mathrm{MgO}\end{array}$ & - & - & - & - \\
\hline & & Major vs Minor & $\begin{array}{l}\mathrm{Fe} \text { vs } \\
\mathrm{Cr}_{2} \mathrm{O}_{3}\end{array}$ & - & - & $\begin{array}{l}\mathrm{Fe} \text { vs } \mathrm{Co} ; \\
\mathrm{Fe} \text { vs } \\
\mathrm{MnO} ; \\
\mathrm{Fe} \text { vs } \\
\mathrm{Cr}_{2} \mathrm{O}_{3} \\
\end{array}$ & - \\
\hline & & Minor vs Minor & $\begin{array}{l}\text { Co vs } \\
\mathrm{MnO}\end{array}$ & $\begin{array}{l}\text { Co vs } \\
\mathrm{MnO}\end{array}$ & $\begin{array}{l}\text { Co vs } \\
\mathrm{MnO}\end{array}$ & $\begin{array}{c}\mathrm{Co} \text { vs } \\
\mathrm{MnO} ; \\
\mathrm{Co} \text { vs } \\
\mathrm{Cr}_{2} \mathrm{O}_{3} ; \\
\mathrm{MnO} \text { vs } \\
\mathrm{Cr}_{2} \mathrm{O}_{3}\end{array}$ & - \\
\hline & \multirow{4}{*}{ Kuat } & Major vs Major & $\begin{array}{l}\mathrm{Fe} \text { vs } \\
\mathrm{Al}_{2} \mathrm{O}_{3}\end{array}$ & & $\begin{array}{c}\mathrm{SiO}_{2} \text { vs } \\
\mathrm{MgO}\end{array}$ & $\begin{array}{l}\mathrm{Fe} \text { vs } \\
\mathrm{Al}_{2} \mathrm{O}_{3}\end{array}$ & \\
\hline & & Major vs Minor & $\begin{array}{c}\mathrm{Fe} \text { vs } \mathrm{Co} ; \\
\mathrm{Fe} \text { vs } \\
\mathrm{MnO} ; \\
\mathrm{Al}_{2} \mathrm{O}_{3} \text { vs } \\
\mathrm{Cr}_{2} \mathrm{O}_{3} \\
\end{array}$ & $\begin{array}{l}\mathrm{SiO}_{2} \text { vs } \\
\mathrm{Co} ; \\
\mathrm{SiO}_{2} \text { vs } \\
\mathrm{MnO}\end{array}$ & - & $\begin{array}{c}\mathrm{Al}_{2} \mathrm{O}_{3} \text { vs } \\
\mathrm{MnO} \\
\mathrm{Al}_{2} \mathrm{O}_{3} \text { vs } \\
\mathrm{Cr}_{2} \mathrm{O}_{3}\end{array}$ & $\begin{array}{c}\mathrm{Fe} \text { vs } \mathrm{Co} ; \\
\mathrm{Fe} \text { vs } \\
\mathrm{MnO} ; \\
\mathrm{Al}_{2} \mathrm{O}_{3} \text { vs } \\
\mathrm{Cr}_{2} \mathrm{O}_{3}\end{array}$ \\
\hline & & Minor vs Minor & $\begin{array}{l}\mathrm{Co} v \mathrm{~s} \\
\mathrm{Cr}_{2} \mathrm{O}_{3} \\
\end{array}$ & - & - & - & 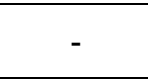 \\
\hline & & Minor vs Minor & $\begin{array}{c}\mathrm{MnO} \text { vs } \\
\mathrm{Cr}_{2} \mathrm{O}_{3}\end{array}$ & $\begin{array}{c}\text { Ni vs Co; } \\
\text { Ni vs } \\
\mathrm{MnO} \\
\end{array}$ & - & - & $\begin{array}{l}\text { Co vs } \\
\mathrm{MnO}\end{array}$ \\
\hline \multirow{4}{*}{ Negatif } & \multirow[b]{2}{*}{ Kuat } & Major vs Major & $\begin{array}{c}\mathrm{SiO}_{2} \text { vs } \\
\mathrm{Al}_{2} \mathrm{O}_{3}\end{array}$ & - & $\begin{array}{l}\mathrm{Fe} \text { vs } \\
\mathrm{MgO}\end{array}$ & $\begin{array}{c}\mathrm{Fe} \text { vs } \\
\mathrm{SiO}_{2} \\
\mathrm{MgO} \text { vs } \\
\mathrm{Al}_{2} \mathrm{O}_{3}\end{array}$ & $\begin{array}{c}\mathrm{Fe} \text { vs } \\
\mathrm{MgO} \\
\mathrm{SiO}_{2} \text { vs } \\
\mathrm{MgO}\end{array}$ \\
\hline & & Major vs Minor & $\begin{array}{c}\mathrm{SiO}_{2} \text { vs } \\
\mathrm{Co} ; \\
\mathrm{SiO}_{2} \text { vs } \\
\mathrm{MnO} ; \\
\mathrm{MgO} \text { vs } \\
\mathrm{Co} ; \\
\mathrm{MgO} \text { vs } \\
\mathrm{MnO}\end{array}$ & $\begin{array}{c}\mathrm{Al}_{2} \mathrm{O}_{3} \text { vs } \\
\mathrm{Ni}\end{array}$ & $\begin{array}{c}\mathrm{Al}_{2} \mathrm{O}_{3} \text { vs } \\
\mathrm{Ni}\end{array}$ & $\begin{array}{c}\mathrm{SiO}_{2} \text { vs } \\
\mathrm{Co} ; \\
\mathrm{SiO}_{2} \text { vs } \\
\mathrm{Cr}_{2} \mathrm{O}_{3} ; \\
\mathrm{MgO} \text { vs } \\
\mathrm{Co} ; \\
\mathrm{MgO} \text { vs } \\
\mathrm{MnO} ; \\
\mathrm{MgO} \text { vs } \\
\mathrm{Cr}_{2} \mathrm{O}_{3} \\
\end{array}$ & - \\
\hline & \multirow[t]{2}{*}{ Sangat Kuat } & Major vs Major & $\begin{array}{c}\mathrm{Fe} \text { vs } \\
\mathrm{SiO}_{2} ; \\
\mathrm{Fe} \text { vs } \\
\mathrm{MgO} ; \\
\mathrm{MgO} \text { vs } \\
\mathrm{Al}_{2} \mathrm{O}_{3}\end{array}$ & $\begin{array}{l}\mathrm{Fe} \text { vs } \\
\mathrm{SiO}_{2} \\
\mathrm{MgO} \text { vs } \\
\mathrm{Al}_{2} \mathrm{O}_{3}\end{array}$ & $\begin{array}{l}\mathrm{Fe} \text { vs } \\
\mathrm{SiO}_{2}\end{array}$ & $\begin{array}{l}\text { Fe vs } \\
\mathrm{MgO}\end{array}$ & - \\
\hline & & Major vs Minor & $\begin{array}{l}\mathrm{SiO}_{2} \text { vs } \\
\mathrm{Cr}_{2} \mathrm{O}_{3} ; \\
\mathrm{MgO} \text { vs } \\
\mathrm{Cr}_{2} \mathrm{O}_{3}\end{array}$ & - & - & - & - \\
\hline
\end{tabular}




\section{MAKALAH ILMIAH}

Tabel 5. Tabel klasifikasi koefisien korelasi hasil analisis multivariat Blok DN

\begin{tabular}{|c|c|c|c|c|c|c|c|}
\hline \multirow{2}{*}{$\begin{array}{l}\text { Angka } \\
\text { Korelasi }\end{array}$} & \multirow{2}{*}{$\begin{array}{l}\text { Tingkat } \\
\text { Korelasi }\end{array}$} & \multirow{2}{*}{$\begin{array}{l}\text { Tipe Unsur } \\
\text { Korelasi }\end{array}$} & \multicolumn{5}{|c|}{ Kategori Zonasi } \\
\hline & & & $\begin{array}{c}\text { Semua } \\
\text { Zona }\end{array}$ & Top Soil & Limonite & Saprolite & $\begin{array}{l}\text { Boulderl } \\
\text { Bedrock }\end{array}$ \\
\hline \multirow{6}{*}{ Positif } & \multirow{3}{*}{ Sangat Kuat } & Major vs Major & $\begin{array}{c}\mathrm{SiO}_{2} \text { Vs } \\
\mathrm{MgO}\end{array}$ & - & - & - & - \\
\hline & & Major vs Minor & $\mathrm{Fe}$ vs $\mathrm{Cr}_{2} \mathrm{O}_{3}$ & $\mathrm{Fe}$ vs $\mathrm{Ni}$ & - & $\begin{array}{l}\mathrm{Fe} \text { vs } \\
\mathrm{Cr}_{2} \mathrm{O}_{3} \\
\end{array}$ & $\mathrm{Fe}$ vs $\mathrm{Cr}_{2} \mathrm{O}_{3}$ \\
\hline & & Minor vs Minor & Co vs $\mathrm{MnO}$ & $\begin{array}{l}\text { Co vs } \\
\mathrm{MnO}\end{array}$ & $\begin{array}{l}\text { Co vs } \\
\mathrm{MnO}\end{array}$ & - & Co vs $\mathrm{MnO}$ \\
\hline & \multirow{3}{*}{ Kuat } & Major vs Major & $\mathrm{Fe}$ vs $\mathrm{Al}_{2} \mathrm{O}_{3}$ & - & - & - & $\mathrm{Fe}$ vs $\mathrm{Al}_{2} \mathrm{O}_{3}$ \\
\hline & & Major vs Minor & $\begin{array}{c}\mathrm{Fe} \text { vs } \mathrm{Co} ; \\
\mathrm{Fe} \text { vs } \mathrm{MnO} ; \\
\mathrm{Al}_{2} \mathrm{O}_{3} \text { vs } \\
\mathrm{Cr}_{2} \mathrm{O}_{3}\end{array}$ & Fe vs Co & - & $\mathrm{Fe}$ vs $\mathrm{MnO}$ & $\begin{array}{l}\text { Fe vs Co; } \\
\text { Fe vs MnO }\end{array}$ \\
\hline & & Minor vs Minor & $\begin{array}{c}\text { Co vs } \\
\mathrm{Cr}_{2} \mathrm{O}_{3} \\
\mathrm{MnO} \text { vs } \\
\mathrm{Cr}_{2} \mathrm{O}_{3} \\
\end{array}$ & $\begin{array}{c}\text { Ni vs Co, } \\
\text { Ni vs } \\
\text { MnO }\end{array}$ & - & - & $\begin{array}{c}\text { Co vs } \\
\mathrm{Cr}_{2} \mathrm{O}_{3} \\
\mathrm{MnO} \text { vs } \\
\mathrm{Cr}_{2} \mathrm{O}_{3}\end{array}$ \\
\hline \multirow{4}{*}{ Negatif } & & Major vs Major & $\begin{array}{c}\mathrm{SiO}_{2} \text { vs } \\
\mathrm{Al}_{2} \mathrm{O}_{3} \\
\end{array}$ & - & - & $\begin{array}{c}\mathrm{SiO}_{2} \text { VS } \\
\mathrm{Al}_{2} \mathrm{O}_{3}\end{array}$ & - \\
\hline & Kuat & Major vs Minor & $\begin{array}{c}\mathrm{SiO}_{2} \text { vs } \mathrm{Co} ; \\
\mathrm{SiO}_{2} \text { vs } \\
\mathrm{MnO} ; \\
\mathrm{MgO} \text { vs Co; } \\
\mathrm{MgO} \text { vs } \\
\mathrm{MnO}\end{array}$ & $\begin{array}{c}\mathrm{Al}_{2} \mathrm{O}_{3} \text { vs } \\
\text { Co }\end{array}$ & - & $\begin{array}{l}\mathrm{SiO}_{2} \text { vs } \\
\mathrm{Co} ; \\
\mathrm{MgO} \text { vs } \\
\mathrm{Co} ; \\
\mathrm{MgO} \text { vs } \\
\mathrm{MnO} \\
\end{array}$ & $\begin{array}{c}\mathrm{MgO} \text { vs Co} \\
\mathrm{MgO} \text { vs } \\
\mathrm{MnO}\end{array}$ \\
\hline & \multirow{2}{*}{ Sangat Kuat } & Major vs Major & $\begin{array}{c}\mathrm{Fe} \text { vs } \mathrm{MgO} ; \\
\mathrm{Fe} \text { vs } \mathrm{SiO}_{2} \\
\mathrm{MgO} \text { vs } \\
\mathrm{Al}_{2} \mathrm{O}_{3}\end{array}$ & - & $\begin{array}{l}\mathrm{Fe} \text { vs } \\
\mathrm{SiO}_{2}\end{array}$ & $\mathrm{Fe}$ vs $\mathrm{MgO}$ & $\mathrm{Fe}$ vs $\mathrm{MgO}$ \\
\hline & & Major vs Minor & $\begin{array}{c}\mathrm{MgO} \text { vs } \\
\mathrm{Cr}_{2} \mathrm{O}_{3} ; \\
\mathrm{SiO}_{2} \text { vs } \\
\mathrm{Cr}_{2} \mathrm{O}_{3}\end{array}$ & $\begin{array}{c}\mathrm{Al}_{2} \mathrm{O}_{3} \text { vs } \\
\mathrm{Ni}\end{array}$ & - & - & - \\
\hline
\end{tabular}

Kriteria korelasi unsur yang dipilih dalam menentukan jumlah unsur adalah minimal 3 korelasi pada masing-masing blok. Hal tersebut ditentukan agar korelasi unsur yang dipilih dapat mewakili terhadap zona lain baik keseluruhan maupun masingmasing zona . Dari hasil pemilihan tersebut, unsur-unsur yang saling berkorelasi baik pada Blok $\mathrm{HZ}$ maupun Blok DN terdapat unsur-unsur terdiri dari unsur major $\left(\mathrm{Fe}, \mathrm{SiO}_{2}\right.$ dan $\mathrm{MgO}$ dan $\mathrm{Al}_{2} \mathrm{O}_{3}$ ) serta unsur minor ( $\mathrm{Ni}, \mathrm{Co}, \mathrm{MnO}$ dan $\mathrm{Cr}_{2} \mathrm{O}_{3}$ ).
Hasil tersebut kemudian dikompilasikan dan diterapkan untuk melakukan interpretasi distribusi profil laterit nikel pada penampang topsoil - limonit- saprolit boulderlbedrock. Pada penampang tersebut secara umum tersusun atas topsoil, limonit, sisipan saprolit di limonit, sisipan boulder di limonit, saprolit, sisipan boulder di saprolit, dan diakhiri dengan boulderlbedrock berikut contoh penampang yang mewakili pada Blok $\mathrm{HZ}$ dan DN (Gambar 8). 


\section{MAKALAH ILMIAH}

(A)

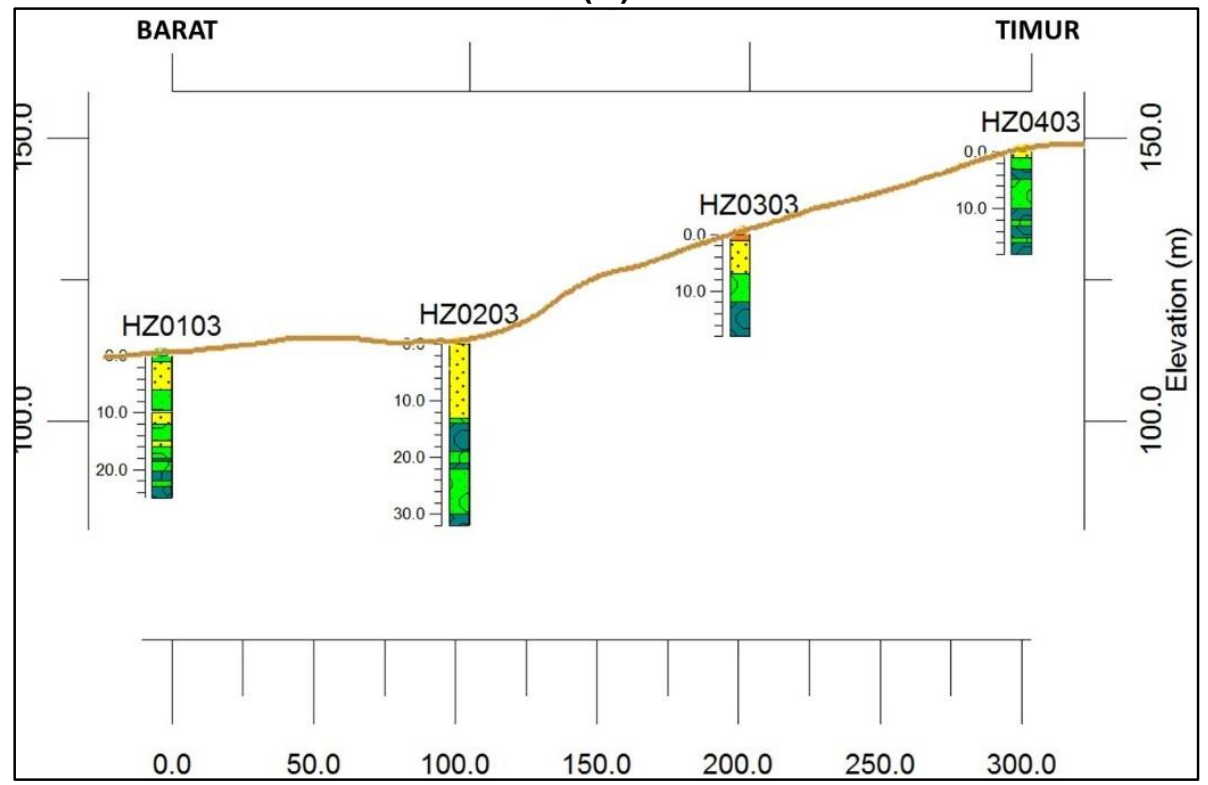

(B)

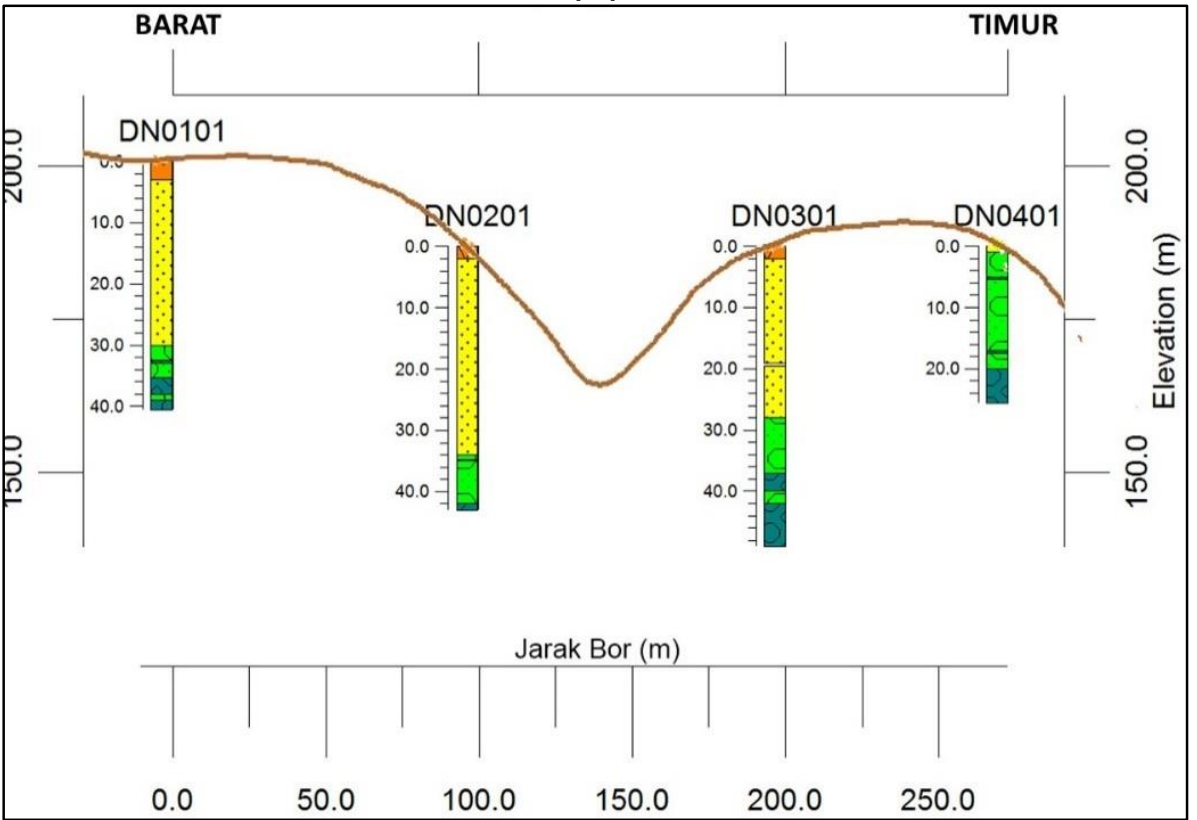

Gambar 8. Penampang hasil pemboran: A, Blok HZ; B, Blok DN

\section{KETERANGAN:}

\begin{tabular}{|l|}
\hline INDEKS LATERIT \\
LIMONIT \\
SOP SOIL \\
SAPROLIT \\
BOULDER/BEDROCK \\
\hline
\end{tabular}

SKALA :

Horz. : Vert.

$1: 2$

\section{INDEKS PENAMPANG}

Blok HZ

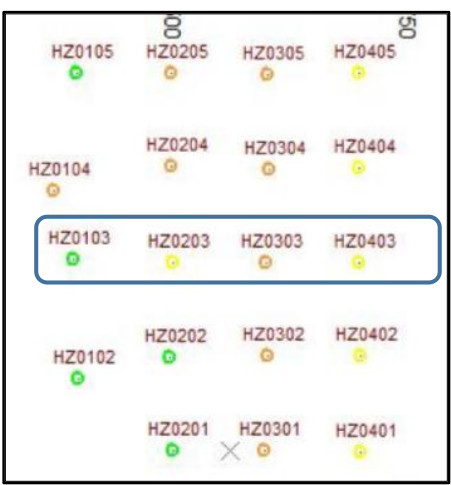

\section{Blok DN}

\begin{tabular}{|c|c|c|c|}
\hline \multicolumn{4}{|c|}{ प्र } \\
\hline DN0104 & DNO204 & DNO304 & DNO404 \\
\hline DN0103 & DNO203 & DNO303 & DNO403 \\
\hline DN0102 & DNO202 & DN0302 & $\underset{\circ}{\mathrm{DN} 0402}$ \\
\hline DN0101 & DNo201 & DN0301 & DN0401 \\
\hline
\end{tabular}

Pada penampang Blok $\mathrm{HZ}$ pada umumnya memiliki susunan laterit nikel relatif tidak teratur dengan kondisi morfologi relatif landai dan miring. Pada penampang Blok DN pada umumnya memiliki susunan laterit nikel relatif tidak teratur pada bagian morfologi miring hingga curam. Namun pada bagian relatif landai memiliki susunan relatif teratur. Adapun pada kondisi relatif landai pada Blok DN memiliki zona limonit relatif tebal.
Agar dapat mengetahui distribusi zona laterit nikel pada blok $\mathrm{HZ}$ maupun $\mathrm{DN}$ terkait unsur yang saling berkorelasi kuat hingga sangat kuat terutama unsur yang mengandung oksida yang memiliki nilai persentase kimia dominan ( $\mathrm{FeO}, \mathrm{MgO}$ dan $\mathrm{SiO}_{2}$ ) disajikan dalam ternary diagram (Gambar 9). 


\section{MAKALAH ILMIAH}

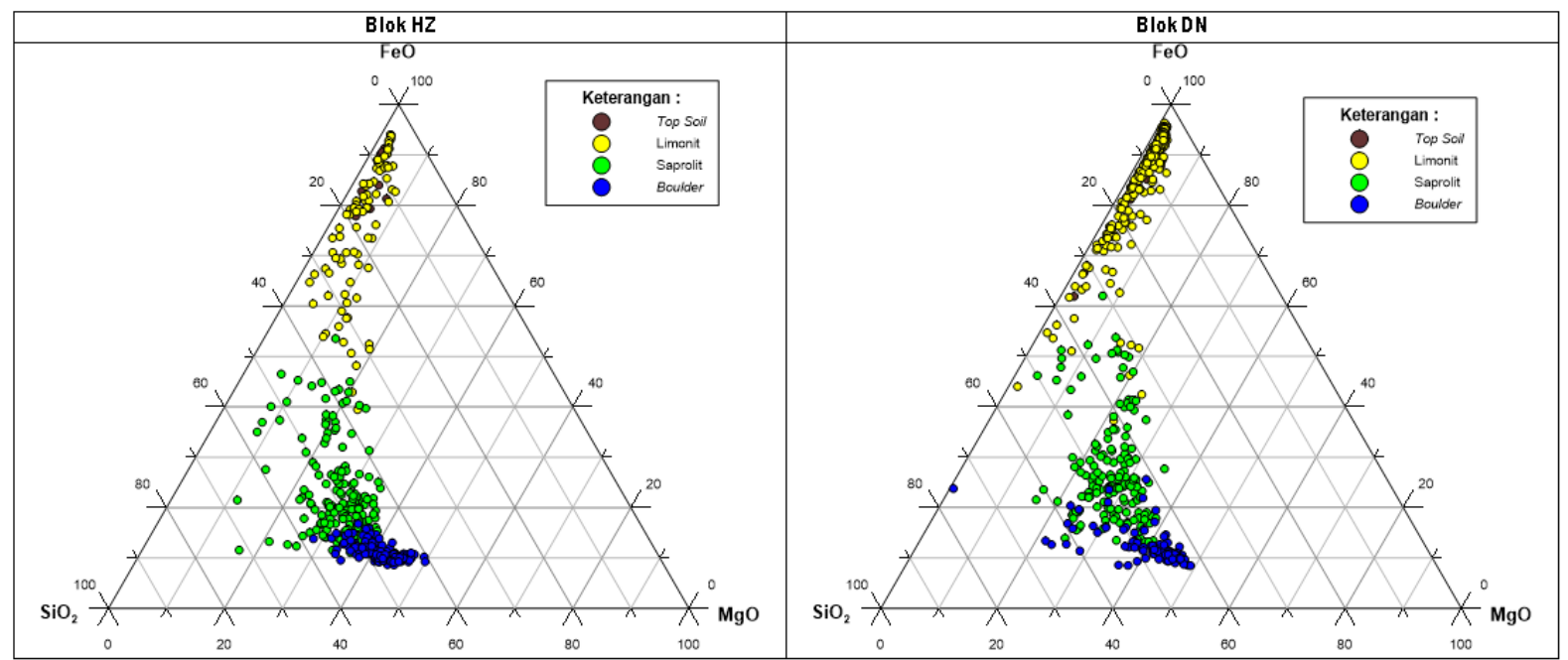

Gambar 9. Ternary diagram distribusi zona laterit nikel Blok HZ dan DN

Diagram tersebut menunjukkan bahwa pada Blok $\mathrm{HZ}$ maupun DN, zona top soil memiliki kadar $\mathrm{FeO}$ relatif tinggi serta kadar $\mathrm{SiO}_{2}$ dan $\mathrm{MgO}$ yang relatif sangat rendah. Pada zona limonit memiliki kadar $\mathrm{FeO}$ relatif sedang ke tinggi serta kadar $\mathrm{SiO}_{2}$ dan $\mathrm{MgO}$ relatif rendah. Pada zona saprolit memiliki kadar $\mathrm{FeO}$ sedang ke sangat rendah serta kadar $\mathrm{SiO}_{2}$ relatif sedang ke tinggi dan $\mathrm{MgO}$ relatif sedang. Pada zona boulder/bedrock, memiliki kadar FeO sangat rendah serta kadar $\mathrm{SiO}_{2}$ relatif sedang tinggi dan $\mathrm{MgO}$ yang sedang. Namun pada Blok DN ditemukan satu conto anomali pada zona boulderlbedrock yaitu memiliki kadar $\mathrm{MgO}$ yang sangat rendah, yang dimungkinkan karena senyawa $\mathrm{MgO}$ tersebut masih terlarutkan dalam air tanah.

\section{PEMBAHASAN}

\section{Hubungan Zonasi Laterit Nikel Berdasarkan Morfologi}

Berdasarkan kondisi morfologi dengan klasifikasi Van Zuidam (1985), zonasi laterit nikel pada Blok $\mathrm{HZ}$ maupun $\mathrm{DN}$ pada umumnya menempati morfologi dengan relief sedikit miring hingga sangat curam dengan tampilan peta sebagai berikut (Gambar 10).

Pada Blok HZ secara detail memiliki sedikit wilayah yang landai hingga miring (sedikit bagian timur) kemudian di dominasi oleh area agak curam (bagian tengah dan timur) hingga curam (bagian utara dan selatan) dan sedikit sangat curam di barat daya blok. Ini berarti bahwa zonasi laterit nikel yang tersusun relatif bervariasi dan tidak sesuai dengan urutan zonasi laterit nikel sehingga terindikasi adanya ketidakteraturan pelapukan. $\mathrm{Hal}$ ini dibuktikan dengan masih adanya sisipan saprolit pada limonit ataupun sisipan limonit pada saprolit, maupun sisipan boulder pada saprolit ataupun sedikit sisipan saprolit pada boulder.

Pada Blok DN yang didominasi oleh area landai hingga miring (utara, tengah, barat, barat daya dan tenggara), sedikit didominasi oleh area curam (utara, timur laut, timur dan sedikit selatan) dan sedikit sangat curam. Ini berarti bahwa zonasi laterit nikel di sebelah barat blok DN relatif terbentuk sesuai urutan zonasi laterit nikel namun masih ada sedikit sisipan boulder pada saprolit yang mengindikasikan ketidakteraturan pelapukan pada zona saprolit dikarenakan pengaruh kondisi morfologi di bagian timur Blok DN. Adapun ketidaksesuaian urutan zonasi laterit nikel pada bagian timur Blok DN terjadi karena kondisi geologinya menyerupai Blok $\mathrm{HZ}$.

\section{Hubungan Zonasi Laterit Nikel Berdasarkan Ketebalan}

Berdasarkan hasil statistik ketebalan yang dibagi berdasarkan blok dan zona laterit 
nikel (Tabel 6), pada umumnya masingmasing blok memiliki ketebalan zona yang tidak terdistribusi normal, yang terlihat dari nilai skewness dan kurtosis serta nilai koefisien variasi (CoefVar) $>0,5$. Ini berarti bahwa distribusi maupun susunan zona laterit nikel di beberapa titik tidak normal dikarenakan kondisi morfologi. Berdasarkan perbandingan ketebalan zonasi laterit nikel di Blok DN, rata-rata memiliki nilai ketebalan yang lebih tebal dari Blok $\mathrm{HZ}$ untuk zonasi laterit nikel secara keseluruhan.

\section{Hubungan Zonasi Laterit Nikel Berdasarkan Distribusi Kimia}

Berdasarkan hasil analisis statistik univariat maupun multivariat terhadap masing-masing unsur yang terdiri dari unsur major $\left(\mathrm{Fe}, \mathrm{SiO}_{2}, \mathrm{MgO}, \mathrm{Al}_{2} \mathrm{O}_{3}\right)$ dan unsur minor ( $\mathrm{Ni}, \mathrm{Co}, \mathrm{MnO}, \mathrm{Cr}_{2} \mathrm{O}_{3}$ ), dari hasil analisis statistik univariat pada umumnya unsur-unsur tersebut terdistribusi tidak normal yang dapat diartikan bahwa distribusi unsur yang dihasilkan tidak homogen dengan nilai koefisien variasi (CoefVar) $>0,5$.

Adapun dari hasil analisis statistik multivariat (Tabel 4 dan 5) unsur-unsur yang memberikan kontribusi dalam penyusunan zona laterit nikel terdiri dari unsur $\mathrm{Fe}, \mathrm{SiO}_{2}, \mathrm{MgO}, \mathrm{Al}_{2} \mathrm{O}_{3}$ (unsur major) dan unsur $\mathrm{Co}, \mathrm{MnO}, \mathrm{Cr}_{2} \mathrm{O}_{3}$ (unsur minor), unsur-unsur tersebut dapat memperlihatkan pola distribusi zonasi laterit nikel. Selain itu dari hasil statistik deskriptif, nilai rata-rata unsur yang dihasilkan pada Blok DN memiliki nilai unsur nikel yang relatif lebih tinggi dari Blok $H Z$. Adapun unsur lainnya yang kadar rataratanya lebih tinggi dari Blok $\mathrm{HZ}$ terdiri dari unsur $\mathrm{Fe}, \mathrm{Al}_{2} \mathrm{O}_{3}, \mathrm{Co}, \mathrm{MnO}$ dan $\mathrm{Cr}_{2} \mathrm{O}_{3}$. Sedangkan unsur pada Blok DN yang kadar rata-ratanya lebih rendah dari Blok $\mathrm{HZ}$ yaitu unsur $\mathrm{SiO}_{2}$ dan $\mathrm{MnO}$.

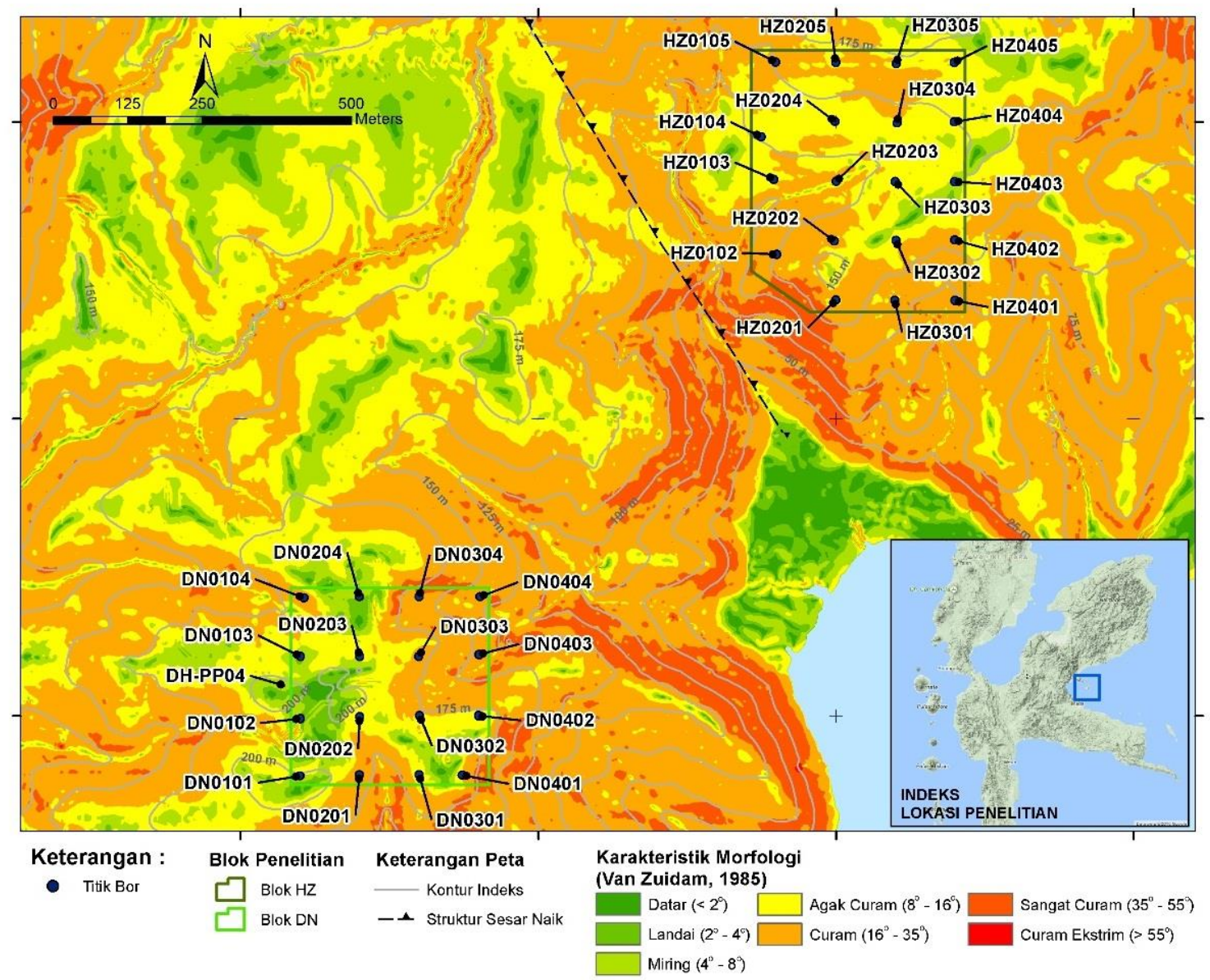

Gambar 10. Peta Morfologi Blok HZ dan DN Daerah Pulau Pakal 


\section{MAKALAH ILMIAH}

Tabel 6. Statistik ketebalan zona laterit nikel Blok HZ dan DN

\begin{tabular}{|c|c|c|c|c|c|c|c|c|c|c|c|}
\hline Blok & ZONA & $\mathbf{N}$ & Mean & Median & StDev & CoefVar & Min & Max & Skewness & Kurtosis & Distribusi \\
\hline \multirow{4}{*}{$\mathrm{HZ}$} & Top Soil & 8 & 1,38 & 1,00 & 0,52 & 0,38 & 1,00 & 2,00 & 0,64 & $-2,24$ & Normal \\
\hline & Limonite & 27 & 3,28 & 2,00 & 3,08 & 0,94 & 0,40 & 13,00 & 1,71 & 3,00 & $\begin{array}{l}\text { Tidak } \\
\text { normal }\end{array}$ \\
\hline & Saprolite & 62 & 2,80 & 2,00 & 2,57 & 0,92 & 0,40 & 12,00 & 1,95 & 3,91 & $\begin{array}{l}\text { Tidak } \\
\text { normal }\end{array}$ \\
\hline & Boulder/Bedrock & 50 & 2,48 & 2,00 & 2,00 & 0,80 & 0,25 & 9,00 & 1,24 & 1,46 & $\begin{array}{l}\text { Tidak } \\
\text { normal }\end{array}$ \\
\hline \multirow{4}{*}{ DN } & Top Soil & 11 & 2,02 & 2,00 & 1,31 & 0,65 & 0,25 & 5,00 & 1,07 & 1,73 & $\begin{array}{l}\text { Tidak } \\
\text { normal } \\
\end{array}$ \\
\hline & Limonite & 21 & 17,59 & 10,00 & 16,90 & 0,96 & 1,00 & 49,60 & 0,68 & $-0,95$ & $\begin{array}{l}\text { Tidak } \\
\text { normal }\end{array}$ \\
\hline & Saprolite & 37 & 4,02 & 2,35 & 3,95 & 0,98 & 0,25 & 18,30 & 1,71 & 3,43 & $\begin{array}{l}\text { Tidak } \\
\text { normal }\end{array}$ \\
\hline & BoulderlBedrock & 35 & 2,12 & 1,00 & 2,23 & 1,05 & 0,30 & 7,60 & 1,32 & 0,57 & $\begin{array}{l}\text { Tidak } \\
\text { normal }\end{array}$ \\
\hline
\end{tabular}

\section{KESIMPULAN}

Hasil pemboran pada litologi harzburgit dan dunit berdasarkan hasil analisis petrologi (megaskopik, mikroskopik dan XRD) pada $\mathrm{EOH}$ (end of hole)/meter akhir conto pemboran bersesuaian dengan hasil analisis kimia untuk setiap Blok $\mathrm{HZ}$ dan Blok DN). Hasil analisis petrologi pada blok $\mathrm{HZ}$ menunjukkan mineral berkomposisi dominan olivin forsterit dan piroksen, sedikit orthopiroksen, generasi awal batuan ultrabasa, berasosiasi dengan mineral opak kromit, kromit, terubah hidrotermal 1 (Rinawan, 2013) dicirikan adanya mineral serpentin krisotil. Pada blok DN mineral yang ditemukan berkomposisi dominan olivin forsterit dan sangat sedikit piroksen, generasi awal batuan ultrabasa, berasosiasi dengan mineral kromit, dicirikan adanya mineral serpentin krisotil.

Berdasarkan hasil analisis kimia secara keseluruhan memiliki unsur kimia yang terdistribusi relatif tidak normal, namun dari hasil analisis tersebut dapat menunjukkan perkembangan laterit yang berbeda antara Blok $\mathrm{HZ}$ dan Blok DN dapat ditunjukkan dengan nilai unsur Nikel berpotensi/relatif tinggi yang berkembang pada zona saprolit. Pada Blok HZ memiliki nilai ratarata lebih kecil daripada Blok DN dimana menunjukkan bahwa distribusi nikel di litologi harzburgit lebih sedikit dari pada litologi dunit.
Berdasarkan kondisi morfologi didominasi oleh agak curam $\left(8^{\circ}-16^{\circ}\right)$ hingga curam $\left(16^{\circ}-35^{\circ}\right)$ serta sedikit landai $\left(2^{\circ}-4^{\circ}\right)$ hingga miring $\left(4^{\circ}-8^{\circ}\right)$ dimana dapat mempengaruhi distribusi kadar unsur major (Fe, $\mathrm{SiO}_{2}, \mathrm{MgO}, \mathrm{Al}_{2} \mathrm{O}_{3}$ ) dan minor ( $\mathrm{Ni}, \mathrm{Co}$, $\mathrm{MnO}, \mathrm{Cr}_{2} \mathrm{O}_{3}$ ) pada masing-masing blok yang dibuktikan pada hasil statistik ditemukan nilai koefisien variasi $>0,5$ dimana distribusi kadar pada unsur tersebut secara keseluruhan terdistribusi tidak normal atau tidak homogen.

Hasil analisis multivariat pada Blok $\mathrm{HZ}$ dan Blok DN terhadap unsur major dan unsur minor untuk keseluruhan maupun masingmasing zona menunjukkan bahwa unsurunsur yang berpotensi memberikan kontribusi dalam penyusunan zona laterit nikel pada Blok $\mathrm{HZ}$ maupun Blok DN terdiri dari $\mathrm{Fe}, \mathrm{SiO}_{2}, \mathrm{MgO}, \mathrm{Al}_{2} \mathrm{O}_{3}$ (unsur major) dan $\mathrm{Co}, \mathrm{MnO}, \mathrm{Cr}_{2} \mathrm{O}_{3}$ (unsur minor). Unsurunsur tersebut yakni memiliki hubungan asosiasi dan resistensi unsur yang kuat hingga sangat kuat sehingga dapat berpotensi memperlihatkan pola penyusunan zona laterit nikel.

\section{UCAPAN TERIMA KASIH}

Ucapan terima kasih yang sebesarbesarnya disampaikan kepada PT Aneka Tambang Tbk. Unit Geomin yang telah memberikan tempat dan data untuk melaksanakan penelitian serta semua pihak yang telah membantu secara 
langsung maupun tidak langsung dalam penelitian ini.

\section{DAFTAR PUSTAKA}

Ahmad, W., 2006, Laterites: fundamentals of chemistry, mineralogy, weathering processes, and laterite formation. PT INCO. 212 hal.

Apandi dan Sudana., 1980, Peta lembar Ternate, Maluku Utara. Pusat Penelitian dan Pengembangan Geologi, Bandung.

Augusman, R. T., 2009, Analisis ketidakpastian dalam estimasi sumber daya nikel laterit menggunakan metode geostatistik, studi kasus endapan nikel laterit di Pulau Pakal, Halmahera Timur, Maluku Utara. Tesis. Fakultas Teknik Pertambangan dan Perminyakan, Institut Teknologi Bandung, Bandung.

Brand, N. M., Butt C. R. M. and Elias, M., 1998, Nickel laterites: classification and features. AGSO Jounal of Australia Geology and Geophysics, Australia 17;81-88.

Elias, M., 2001, Global lateritic nickel resources. New Caledonian Nickel Conference. Pty Ltd CSA, Australia.

Elias, M., Butt. C. R. M., 2003, Nickel lateritic: A. Review. SEG Newsletter 54; 9-15.

Harraz, H. Z., 2015, Topic 8: Residual (eluvial or laterite) mineral deposits. $09 \quad$ Desember 2015. http://www.slideshare.net/hzharraz/r esidualmineral deposits.

Harris, R., 2003, Geodynamic patterns of ophiolites and marginal basins in the indonesian and New Guinea Regions. Geological Society, London, Special Publications, 218 (1), pp.481-505.
Ishiwatari, A., 1994, Circum-Pacific Phanerozoic multiple ophiolite belts. In Circum-Pacific Ophiolites (Proceedings of the 29th IGC Ophiolite Symposium) (pp. 7-28).

Kadarusman, A., 2001, Geodynamic of Indonesian region; a petrological approaches. unpublished PhD Thesis. Tokyo Institute of Technology.456p.

Rinawan, F. I. W., Rosana, M. F., Patonah A., Agustini, S., 2013, Batuan ultramafik dan keterdapatan laterit nikel di Pulau Pakal, Kabupaten Halmahera Timur, Maluku Utara. Fakultas Teknik Geologi, Universitas Padjadjaran, Bandung.

Sinclair, A. J., Blackwell, G. H. 2004, Applied mineral inventory estimation. Cambridge University Press, Cambridge.

Sugiyono. 1999, Statistik Untuk Penelitian. CV Alfabeta, Bandung.

Syafrizal, Heriawan, M. N., Notosiswoyo, S., Anggayana, K., Samosir, J. F., 2009, Hubungan kemiringan lereng dan morfologi dalam distribusi ketebalan horizon laterit pada endapan nikel laterit, studi lasus endapan laterit nikel Pulau Gee dan Pulau Pakal, Halmahera Timur, Maluku Utara. JTM Vol. XVI No. 3/2009.

Van Zuidam, R. A. 1985, Aerial photointerpretation in terrain analysis and geomorphologic mapping. Smits Publishers. International Institute for Aerospace Survey and Earth Sciences.

\begin{tabular}{|ll|}
\hline Diterima & $:$ 17 September 2018 \\
Direvisi & $: 24$ September 2018 \\
Disetujui & $: 29$ November 2018 \\
\hline
\end{tabular}

